\title{
Grooming Tomorrow's Change Agents: The Role of Law Schools in Helping to Create a Just Society
}

\begin{abstract}
Jonathan A. Rapping*
Numerous authorities have lamented the fact that America's criminal justice system is broken. To address this crisis, experts proposed a range of policy proscriptions. But, these proposals overlook a fundamental driver of this state of injustice. The criminal justice system, as it now exists, is defined by a value system inconsistent with justice. And many professionals responsible for administering criminal justice-politicians, judges, prosecutors, and defense counsel-have been shaped by this corrupted value system. As a result, those responsible for justice in America frequently promote unjust outcomes. If we are ever to realize meaningful reform, we must groom a generation of professionals who embrace those ideals fundamental to American justice, and work together to infuse the criminal justice system with these values. Because so many of these professionals are lawyers, our nation's law schools must play an indispensable role in this effort. Critics have identified some significant shortcomings in legal education. Many pointed to the failure of law schools to teach skills and values essential to the practice of law. Some have urged law schools to inspire graduates to find careers that promote the public interest. But largely overlooked is the need to equip lawyers with strategies to promote justice in broken systems. If law schools are going to fulfill their obligation to help us realize our most noble ideals, they must develop curricula designed to not only teach lawyers values and motivate them towards social justice careers, but to also arm them with tools to resist systems hostile to the principles that define us as a nation. This article discusses this challenge and examines two efforts to equip young lawyers with tools and strategies to become the change agents necessary to drive reform; one through an innovative
\end{abstract}

Jonathan A. Rapping is an Associate Professor at Atlanta's John Marshall Law School (AJMLS) where he also serves as the Director of its Honors Program in Criminal Justice. He is the Founder and President of Gideon's Promise, an organization dedicated to creating a generation of public defenders to drive a transformation in criminal justice. He is currently on leave from AJMLS to serve as the Director of Strategic Planning and Organizational Development for the Maryland Office of Public Defense. Special thanks to Elayne Rapping for her editorial advice, Jasmine Barber for her research assistance, the faculty of AJMLS for its commitment to the Honors Program in Criminal Justice, and the staff, faculty, and public defenders of Gideon's Promise for working to change the culture of criminal justice in our nation's most broken systems. 
law school curricula and the other through the training and mentoring of lawyers post law school in the crucial arena of indigent defense.

\section{INTRODUCTION}

As I sat down to begin writing this introduction, a friend sent me an article about Jeff Mizansky, a Missouri man who has already served twenty-one years of a sentence of life without parole for a non-violent marijuana offense. Jeff was caught on surveillance tape accompanying another man to purchase a significant amount of marijuana. He never touched the marijuana. No firearms or minors were involved. And while he had two prior convictions for non-violent marijuana crimes, he never served a day in prison before this sentence. Before I became a student of criminal justice in America, I would have been shocked. As I read this account, I was sadly not surprised. The story is not exceptional. Lawmakers routinely support unconscionable laws in an effort to appear tough on crime, without regard for the human lives or the foundational principles that define our democracy that they trash in the process. Throw in a prosecutor who uses every tool available to coerce the accused into giving up his constitutional rights, a defender too overburdened to begin to sufficiently defend him, and a judge more concerned about moving a massive docket efficiently than ensuring the results are fair, and this is the story of justice in America. ${ }^{1}$

The United States of America locks up its citizens at a significantly higher rate than any other country in the world. ${ }^{2}$ In the past four decades the breadth of criminalized behavior has ballooned and punishment has become increasingly more draconian. ${ }^{3}$ More non-violent offenders are locked away in inhumane conditions for longer periods of time here than anywhere else. ${ }^{4}$ Such is the story of the "Land of the Free."

This mass incarceration crisis does not impact all of us equally. Eightypercent of those brought into the criminal justice system are severely

1 I do not know, nor suggest, the extent to which these generalizations describe the behavior of the criminal justice professionals in Mr. Mizansky's case. But the described behavior is all too common and frequently combines to drive outcomes similarly unjust as Mr. Mizansky's.

2 Peter Wagner, Leah Sakala \& Josh Begley, States of Incarceration: The Global Context, PRISON POLICY INITIATIVE, http://www.prisonpolicy.org/global/ (last visited May 24, 2015) (showing that not only does the United States have the highest incarceration rate of any country, but that thirtysix states and the District of Columbia have higher incarceration rates than any country in the world other than the United States).

3 Jonathan A. Rapping, Who's Guarding the Henhouse? How the American Prosecutor Came to Devour Those He is Sworn to Protect, 51 Washburn L. J. 513, 534 (2013) [hereinafter Henhouse] (portions of the discussion in this section come directly from Henhouse).

4 Id. See also John Conyers, Jr., The Incarceration Explosion, 31 YALE L. \& PoL'y Rev. 377, 385 ("Mandatory sentences, long sentences for nonviolent first offenses, and laws mandating increased penalties for repeat offenders lead to overincarceration."). 
impoverished. ${ }^{5}$ They are disproportionately non-white. ${ }^{6}$ If you are poor and of color, you are significantly more likely to be surveilled, arrested, charged, prosecuted, convicted, sentenced to a lengthy term of imprisonment, and subjected to collateral consequences. ${ }^{7}$ Such is the hypocrisy of our "equal justice under the law."

And those who are responsible for administering a system of justice that, in theory, is meant to ensure every individual's fundamental protections before being deprived of his or her liberty, has lost sight of this role. Roughly ninety-seven percent of those accused of a crime plead guilty and give up their rights to avail themselves of the myriad of protections our Founding Fathers deemed essential to ensure justice. $^{8}$ Prosecutors are more adept at coercing pleas than at ferreting out truth. Public defenders are too overwhelmed to ensure their clients receive all the protections those who penned the Bill of Rights envisioned, and judges have become resigned to a role of overseeing a massive operation that processes people from arrest to sentencing. Such is the reality of "due process."

There is no better gauge of the health of American democracy than the way human beings are treated in our criminal justice system. At the very core of who we are as a nation is a deep-seated respect for individual liberty and an appreciation of the need to jealously guard it against the inherent abuses of government. Our nation is founded on the idea that a government unchecked morphs into tyranny, threatening the ideals that define us as a nation. Our Founding Fathers painstakingly laid out a set of individual rights deemed essential to a democratic society. They serve as protections, creating a buffer between the individual and the State when the latter threatens the liberty of the former.

Our commitment to these principles depends on the idea that justice is independent of one's station in life. They are to be applied fairly and with an even hand, blind to issues such as class and race.

Sadly, we have abandoned those ideals in the very realm where individual liberty is most threatened, the criminal justice arena, leaving all of us subject to the tyranny our founders so recoiled against. And while this abandonment undermines who we claim to be as Americans, to further reinforce how this jeopardizes our democracy, the government has used its unchecked power to disproportionately victimize the most vulnerable among us.

Today, our criminal justice system represents an enormous, largely unchecked, government effort to subject Americans to increasingly harsh deprivations of liberty. This effort is almost exclusively aimed at our poorest citizens and disproportionately at those who are of color. At every level, our

\footnotetext{
5 Jonathan A. Rapping, Implicitly Unjust: How Defenders Can Affect Systemic Racist Assumptions, 16 N.Y.U. J. LEGIS. \& PUB. POL'Y 999, 1018 (2013).

6 Id.

7 Id. at 1006

8 William J. Stuntz, The Collapse of American Criminal Justice 7 (2011).
} 
nation's law enforcement machinery violates our most cherished ideals. Everything we stand for as a nation is tarnished by our failure to administer criminal justice consistent with our ideals.

Much has been written about how broken our criminal justice system is and what we need to do to right its wayward course. The discourse primarily focuses on the need for policy reform-reallocating resources and engaging in structural modifications. But, too little attention is paid to the role that individuals at every level of the system - driven by a misguided set of values and assumptions - have come to accept, thus perpetuating the current state of injustice. If we are to truly transform the criminal justice system in the image of what we purport it to be as Americans, we will need to inspire criminal justice professionals to reexamine their roles in promoting justice and prepare them with a set of strategies to transform the status quo.

In this article I argue that the transformation begins with the role of law schools in preparing legal professionals for their work. Because discussions about criminal justice reform have overlooked the values and assumptions that shape our collective behavior involving the administration of criminal justice, they have failed to consider the role-indeed, the obligation I would argue - that America's law schools might play in propelling criminal justice reform. Because the ideals that form the bulwark of our criminal justice system rank among the most cherished of all legal (and human) concepts, law schools should address these challenges prominently in their curricula. Because so many of the people who influence and drive criminal justice are lawyers, law schools are uniquely positioned to affect change. And, because law schools have a monopoly on how lawyers are educated, they have an obligation to address this national crisis.

But, law schools collectively fall well short of meeting this obligation. In fact, an entire body of scholarship is devoted to examining how law schools fail to even train graduates to practice law generally, let alone inspire them to address our nation's greatest challenges and teach them to do so effectively. This article argues that law schools play a critical role in reforming our criminal justice system and, thereby, helping to restore our democratic ideals. But to do so, we must move beyond a discussion of simply how to better prepare graduates to be "practiceready." We need to also inspire lawyers to commit their talents to address issues that threaten our ideals. But even this is not enough. We must also provide our graduates with tools to reshape these systems. Our nation's criminal justice system does not only need good lawyers, it also needs an army of change agents to reshape it. Law schools must begin building that army.

In the first part of this paper I posit that an examination of the administration of our criminal justice system provides the most accurate insight into the extent to which we are living up to our democratic ideals. I further argue that based on this metric, we have fallen well short of realizing who we claim to be as Americans.

In the next section I argue that the greatest obstacle to reforming our criminal justice system is the fact that the professionals who work within it have come to embrace a set of values and assumptions that are inconsistent with our 
constitutional ideals. Having lost sight of the founding values and goals that define American justice, this group of professionals is incapable of overseeing a transformation of this system.

I next argue that because we have failed to sufficiently appreciate this aspect of the problem, little attention has been given to the need to develop a community of criminal justice professionals who appreciate and embrace those values so essential to our democracy, and who are equipped with the necessary tools to ensure our criminal justice system operates consistently with them. Because so many of these professionals must graduate from one of our nation's law schools, these institutions play a critical role in any criminal justice reform effort.

I next turn to an examination of law school curricula and the ways in which it fails to prepare the criminal justice professionals needed for this effort. I argue that if law schools are to respond to this crisis, they must reimagine a curriculum that does three things: better prepares students to practice in the field of criminal law, inspires students to consider careers in criminal law, and provides students with a set of tools and strategies to transform the systems in which they work to be in accord with our founding principles of justice. This section will build on a body of scholarship that discusses legal academia's failure to produce "practice-ready" graduates and suggests that addressing this concern is the first step in the instant analysis. Little has been written about the need to encourage students to consider careers that promote public interest. And less still considers how to prepare students who are so inclined to serve as change agents in dysfunctional legal environments. This section will address these concerns.

I finally look to two initiatives that are instructive for this discussion. First, examining the work of the non-profit organization Gideon's Promise, I demonstrate how its model for developing a community of reform-minded public defenders is doing this with recent law graduates. However, it is unfortunately left to do the work that should have been part of these lawyers' legal education. I next discuss an initiative called the Honors Program in Criminal Justice, launched at Atlanta's John Marshall Law School in 2011. This program serves as a template for law schools committed to preparing criminal justice practitioners who view their role as working to reshape the criminal justice system to better realize our Founding Father's notion of justice, and who are equipped with strategies for doing so.

While both of these efforts are important examples of the work that desperately needs to be done if we are to transform our system of justice, we must more widely embrace the idea of values-based training for all criminal justice professionals if we are to ever realize meaningful reform. Law schools must become a partner in this process.

\section{AMERICAN CRIMINAL JUSTICE: A REFLECTION OF OUR HighEST IDEALS}

Before turning to the role of law schools, let us look briefly at the originating ideas that form the basis of what law schools are tasked to teach about justice. For 
nearly 600 years before the drafting of the United States Constitution, dating back to the Magna Carta, ${ }^{9}$ our constitutional forefathers struggled to rein in the power of the king and to ensure individual liberty was protected. ${ }^{10}$ This experience informed the attitudes of early American colonists, who came to the New World with a strong distrust of authority and an acute understanding of how, without sufficient safeguards, government will become oppressive towards those it governs. ${ }^{11}$ The struggle with the Crown continued in colonial America, and as the king's representatives did his bidding in the colonies, that distrust grew to include all government agents. ${ }^{12}$ Justice in early America was focused on protecting the individual against the excesses of government, as the colonists understood that a government unchecked led to tyranny. The men who drafted the American Constitution carefully constructed procedural protections designed to limit the power of the government and to secure citizens' substantive rights. Because they knew from experience that unchecked power and liberty are naturally antagonistic, these safeguards were indispensable to the constitutional democracy they designed.

Those rights deemed most fundamental to our core ideals were laid out in the Bill of Rights and served to protect the rights of the minority against an oppressive government representing the will of the majority. ${ }^{13}$ The values reflected in the Bill of Rights were meant to influence many aspects of American society, but in no arena was its influence more imperative than criminal justice, where an overreaching government poses the greatest threat to individual liberty. The experience with King George III and his minions taught American colonists about the "voracious persistence with which government power seeks to avoid the legal limits that secure our rights." 14 The Constitution, and accompanying Bill of Rights, would serve as a bulwark against this threat. Three features of the American system of procedural safeguards most essential to protecting the people from the despotic inclinations of government include the right to counsel, trial by jury, and an independent judiciary. These three protections are as fundamental to the health of our democracy as any.

Fundamental to our system of justice is the notion, which can be traced back to the Magna Carta, that before one may be deprived of his or her liberty by his government, the fight must be fair. The accused must have the opportunity to prepare his defense, to challenge the allegations against him, and to ensure that basic rights are protected in the process. As the Supreme Court made clear in the

9 See Ira Glasser, Visions of Liberty: The Bill of Rights for All Americans 21-61 (1991) (providing an excellent summary of the development of those principles fundamental to the American Constitution dating back to the Magna Carta, Latin for "Great Charter" and agreed upon in 1215).

See Henhouse, supra note 3, at 523-28.

$I d$.

See id. at 524.

See GLASSER, supra note 9, at 41.

See id. at 27. 
seminal case of Powell v. Alabama, none of these values can be realized without a lawyer "skill[ed] in the science of law." "In every criminal case, a lawyer must have the time and skill to undertake essential preparatory tasks such as conducting investigation, seeking discovery, and researching and litigating pre-trial motions. ${ }^{16}$ A lawyer must be available to protect the accused's "fundamental rights"; i.e., those Constitutional rights deemed "essential to a fair trial." ${ }^{\text {"17 }}$ Every safeguard the Framers viewed as foundational to our system of justice is at risk without counsel to ensure their protection.

In addition to having a lawyer to protect the accused's most basic rights, the framers viewed the right to trial by jury as "an inestimable safeguard against the corrupt or overzealous prosecutor." 18 Our forefathers' experience in England left them fearful of the unchecked power of government. ${ }^{19}$ As Professor Paul Butler reminds us "The Constitution was written by men who were very suspicious of the power of Government. Prosecutors were viewed as a necessary evil, but the framers didn't trust them much. Thus the right to trial by jury was guaranteed in the Bill of Rights." 20

"The jury remains one of the nation's most vital democratic institutions, enabling ordinary citizens to block tyrannical actions by government." ${ }^{21}$ This

15 Powell v. Alabama, 287 U.S. 45, 68-69 (1932). The Court discussed the importance of counsel as follows:

The right to be heard would be, in many cases, of little avail if it did not comprehend the right to be heard by counsel. Even the intelligent and educated layman has small and sometimes no skill in the science of law. If charged with crime, he is incapable, generally, of determining for himself whether the indictment is good or bad. He is unfamiliar with the rules of evidence. Left without the aid of counsel he may be put on trial without a proper charge, and convicted upon incompetent evidence, or evidence irrelevant to the issue or otherwise inadmissible. He lacks both the skill and knowledge adequately to prepare his defense, even though he have a perfect one. He requires the guiding hand of counsel at every step in the proceedings against him. Without it, though he be not guilty, he faces the danger of conviction because he does not know how to establish his innocence. If that be true of men of intelligence, how much more true is it of the ignorant and illiterate, or those of feeble intellect.

16 See Jonathan A. Rapping, You Can't Build on Shaky Ground: Laying the Foundation For Indigent Defense Reform Through Values-Based Recruitment, Training, and Mentoring, 3 HARV. L. \& POL'Y REV. 161, 169-70 (2009) [hereinafter Shaky Ground].

17 Gideon v. Wainwright, 372 U.S. 335, 343-44 (1963). In addition to the right to counsel and to trial by jury, which are discussed more fully in this article, included among these fundamental rights are the right to be free from unreasonable searches and seizures and to have excluded from criminal trials any evidence illegally seized, to be free of compelled self-incrimination, to a speedy and public trial, to confront opposing witnesses, and to compulsory process to secure witnesses for one's defense. See Duncan v. Louisiana, 391 U.S. 145, 148-49 (1968) (laying out the rights held to be fundamental).

18 Duncan, 391 U.S. at 156.

19 See Nancy J. King, Duncan v. Louisiana: How Bigotry in the Bayou Led to the Federal Regulation of State Juries, in Criminal Procedure StORIES 276-77 (Carol S. Steiker ed., 2006).

20 Paul Butler, Let's Get Free: A Hip-Hop Theory of Justice 61 (2009).

21 King, supra note 19, at 261. 
sacred right was recognized as "inherent and invaluable to every [colonist]" is enshrined in both the body of our Constitution and the Sixth Amendment to the Bill of Rights. ${ }^{23}$ In finding the right to trial by jury in a criminal case to be fundamental to our system of justice, the Supreme Court made clear in Duncan $v$. Louisiana, that while the government has the power to accuse an individual of wrongdoing, a jury ultimately must be available to decide whether such allegations are warranted. This buffer between the accused and a prosecutor hell-bent on securing a conviction serves as a "barrier[] . . . against the approaches of arbitrary power." ${ }^{24}$ In short, the right to a trial by jury is an essential element of justice in America. ${ }^{25}$

While the jury is an essential component of a justice system devised by men who harbored a "profound mistrust of government," 26 it alone was not seen as providing sufficient protection to the individual in the criminal justice arena. Another critical safeguard was the separation of powers doctrine. This doctrine carved out a critical role in our criminal justice system for the judicial branch. The fundamental role of an independent judiciary to our system of justice is reflected in our devotion to separation of powers and preserved in the text of our Constitution. ${ }^{27}$ At "the heart of our constitutional scheme, [separation of powers doctrine] enables the judiciary to perform this role fearlessly, effectively, and independently." 28

The Framers "recognized that "the accumulation of all powers, legislative, executive, and judiciary, in the same hands . . . may justly be pronounced the very

22 As the Court articulated in Duncan:

Among the resolutions adopted by the First Congress of the American Colonies (the

Stamp Act Congress) on October 19, 1765-resolutions deemed by their authors to state 'the most essential rights and liberties of the colonists' — was the declaration: 'That trial by jury is the inherent and invaluable right of every British subject in these colonies.' (citations omitted) Duncan, 391 U.S. at 152.

${ }_{23}$ U.S. CONST. art. III, $\S 2$ provides that: "The trial of all crimes except in cases of impeachment shall be by jury ... ." The Sixth Amendment provides: "In all criminal prosecutions, the accused shall enjoy the right to a speedy public trial, by an impartial jury of the State and district wherein the crime shall have been committed." U.S. CONST. amend. VI.

24 Duncan, 391 U.S. at 154 (citing Thompson v. State of Utah, 170 U.S. 343, 349-50 (1898)).

25 See Williams v. Florida, 399 U.S. 78, 100 (1970) ("the essential feature of a jury obviously lies in the interposition between the accused and his accuser of the commonsense judgment of a group of laymen, and in the community participation and shared responsibility that results from that group's determination of guilt or innocence.").

26 Hans H. Grong, Toward a Robust Separation of Powers: Recapturing the Judiciary's Role at Sentencing, 92 MinN. L. REV. 1584, 1600 (2008).

27 Burkeley N. Riggs \& Tamera D. Westerberg, Judicial Independence: An Historical Perspective the Independence of Judges Is . . Requisite to Guard the Constitution and the Rights of Individuals . . ., 74 DENV. U. L. REV. 337, 338 (1997) ("Article III of the United States Constitution preserves the independence of judges in their decision making process.").

28 Irving R. Kaufman, The Essence of Judicial Independence, 80 Colum. L. REv. 671, 671 (1980). 
definition of tyranny." 29 Separation of powers was meant to prevent the accumulation of power before it occurred. ${ }^{30}$ "The framers recognized that the criminal process is particularly ripe for abuses and carefully crafted a system to minimize that possibility." 31 Within constitutional limits, the legislative branch has the authority to define criminal conduct. The executive branch, through its prosecuting agents, maintains the discretion to charge an individual criminally. The jury's role is to adjudicate guilt. "The judge's role is to sentence individuals who have been convicted by a jury based on his discretion and experience." 32 This thoughtful balance helps to ensure that no branch of government is able to "subvert popular sovereignty and individual liberty." 33

Each of these protections - the right to counsel, the right to trial by jury, and an independent judge responsible for resolving legal disputes and determining punishment - is an essential component of America's justice system. Each makes it harder for the government to deprive the individual of his or her liberty. Ours is a system in which justice is determined by how faithful we are to this process, so important to our constitutional democracy.

Our Founding Fathers saw the trial process as the vehicle through which we determine whether the accused is guilty of the alleged crime and, if so, the appropriate punishment. ${ }^{34}$ The prosecutor decides whether to charge an individual and, if so, with what crime(s). In carrying out this role, the ideal prosecutor serves as a minister of justice, ${ }^{35}$ striving to achieve fair results, and taking into account all circumstances. Once accused, justice demands that the individual be provided counsel with the experience, training, and resources necessary to ensure that all of the individual's rights are protected during the course of the prosecution. Individual liberty is further protected by having both sides present their case to a jury of the accused's peers to determine whether the government has sufficiently proven its case. And finally, if convicted, the accused is entitled to a neutral judge to determine the appropriate punishment. Each of these players represents an essential component to our system of justice: a prosecutor motivated to pursue

29 Grong, supra note 26, at 1600 (citing THE FEDERALIST No. 47 at 307-08 (James Madison) (Robert Scigliano ed., 2000)).

30 Id. at 1600-01 (citing ThOMAs JefFerson, Notes ON THE StATE OF Virginia 121 (William Peden ed., University of North Carolina Press 1982)).

31 Id. (citation omitted).

32 Id. at 1603 (citation omitted).

33 Id. (citation omitted).

34 Susan Haack, Of Truth, In Science and In Law, 73 BrooK. L. Rev. 985, 985-86 (2008). [A] trial is better described as a late stage of a process of determining a defendant's guilt or liability: the stage at which, under the legal guidance of the court, advocates for each side present evidence in the light most favorable to their case, and the finder of fact sifts through it and assesses whether it establishes guilt or liability to the required degree of proof.

Id.

35 See Henhouse, supra note 3, at 520-23. 
justice, defense counsel faithful to his or her duty to the accused, a jury of the accused's peers to determine whether the government can in fact prove the allegations, and an unbiased judge who decides on the appropriate punishment if the individual is convicted. Only by ensuring all rights are realized and that the power to decide the individual's fate is sufficiently dispersed throughout the process, can justice consistent with our constitutional ideals be achieved.

Unfortunately, we have strayed far from our fidelity to these concepts. Our criminal justice system has gravitated to a state that would make the drafters of our Constitution shudder. Rather than a system in which criminal justice professionals are guided by those values that define American justice, ours more closely resembles an assembly line through which people are processed with little attention paid to those protections embodied in our Constitution.

Our criminal justice system suffers from a case of gigantism. We have experienced a steady increase in rates of arrest. ${ }^{36}$ Prosecutors, succumbing to public pressure to be "tough on crime," charge far more cases than the system is equipped to handle. ${ }^{37}$ Judges, pressured to value efficiency over justice, have become adept at moving cases through their dockets quickly. ${ }^{38}$ Defense counsel who are overwhelmed and under-resourced, succumb to the pressure to help process their clients through the system. ${ }^{39}$ And, predictably, incarceration rates have steadily increased. ${ }^{40}$ Yet, the resources necessary to ensure that this critical work is being done consistent with justice have not kept pace. ${ }^{41}$ All across the

36 Surell Brady, Arrests Without Prosecution and the Fourth Amendment, 59 MD. L. REv. 1, 20-21 (2000) ("The state arrest laws have at least three immediate consequences. . . . [one being] the blanket authority of police officers to conduct arrests . . . undoubtedly result[ing] in far more arrests . ...").

37 See Henhouse, supra note 3, at 538-39 (discussing caseloads of prosecutors); see also Brady, supra note 36, at 49 ("One likely result [of continuation of or increases in arrest rates that grossly outpace the allocated criminal justice resources] is an arithmetical impossibility to prosecute the majority of cases brought into the system by arrests.").

38 Albert W. Alschuler, Courtroom Misconduct By Prosecutors and Trial Judges, 50 TEX. L. REV. 629, 679 (1972) ("Many trial judges seem to have become as preoccupied with 'moving cases' as traffic police are with moving vehicles.”).

39 Shaky Ground, supra note 16, at 166.

40 Matthew B. Kugler et al., Differences in Punitiveness Across Three Cultures: A Test of American Exceptionalism in Justice Attitudes, 103 J. CRIM. L. \& CRIMINOLOGY 1071, 1073-74 (2013) ("The past fifty years have seen a rise in concern about crime in the United States and, concurrently, in the national incarceration rate. .. The United States now has the highest incarceration rate in the world, [and] assigns more long-duration prison sentences than do other countries ....").

${ }_{41}$ See Adam M. Gershowitz \& Laura R. Killinger, The State (Never) Rests: How Excessive Prosecutorial Caseloads Harm Criminal Defendants, 105 Nw. U. L. REV. 261, 287 (2011) (discussing how the expanding criminal justice system impacts prosecutors); see also ABA Standing Comm. on Legal Aid \& Indigent Defendants, Gideon's Broken Promise: AmericA's Continuing Quest fOR EQuAL Justice iv (2004) (Overall, our hearings support the disturbing conclusion that thousands of persons are processed through America's courts every year either with no lawyer at al or with a lawyer who does not have the time, resources, or in some cases the inclination to provide 
country our criminal justice system is overwhelmed. But rather than banding together to resist pressure to administer a system that is not resourced to do so consistent with justice, America's criminal justice professionals have adapted to the status quo. Criminal justice professionals have learned to process growing caseloads swiftly, and in doing so they have lost sight of our most cherished values. The result is a criminal justice system in which the fundamental rights discussed above are disregarded. Over ninety-five percent of those convicted and subjected to a deprivation of liberty plead guilty, forgoing their right to those protections so vital to our system of justice. ${ }^{42}$ The jury trial, which was designed to be the vehicle through which justice was realized, has become a relic of another era. The criminal justice system has morphed into a process in which the role of the jury and the judge are marginalized to the point of near non-existence. Without sufficient resources to justly handle our criminal caseload, we have become the world our Founding Fathers so feared; one in which the executive branch can levy an accusation, ensure a swift conviction, and determine whatever punishment it wishes, leaving the individual without any meaningful opportunity to contest the accusations against him.

In a previous article, I posited the following analogy:

[A]ssume the public demanded that 500 miles of public state highway be built but the legislature only provided enough funding to safely construct one-fifth of the project. The state could build 100 miles of highway consistent with safety standards or build 500 miles of highway, none of which is sound enough to protect its travelers. No responsible government would opt for the latter. Yet, we do this every day in America's criminal justice system . . . 43

As in this highway analogy, every criminal justice professional knows that the resources do not exist to ensure that every person receives the protections discussed above. But contrary to what we would predict the response to be in the highway example, rather than refusing to proceed with cases where there are insufficient resources to do so consistent with justice, lawyers and judges routinely work to facilitate the process. And just as would be inevitable should drivers be left to rely on structurally deficient highways, there is an enormous human toll from our decision to proceed with a structurally deficient criminal justice system. ${ }^{44}$

effective representation.), available at http://www.americanbar.org/content/dam/aba/administrative /legal_aid_indigent_defendants/ls_sclaid_def_bp_right_to_counsel_in_criminal_proceedings.authcheckdam.pdf.

42 Stuntz, supra note 8, at 7. See also Missouri v. Frye, 132 S. Ct. 1399, 1407 (2012) (where Justice Kennedy acknowledged that "ours 'is for the most part a system of pleas, not a system of trials ....'"').

43 Henhouse, supra note 3, at 555.

44 Mark Mauer \& Meda Chesney-Lind, Introduction, in Invisible Punishment: The Collateral Consequences of Mass ImPrisonment 1, 5 (Mark Mauer \& Meda Chesney-Lind eds., 2002) (quoting A.B.A. Task Force on Collateral Sanctions, Introduction to Proposed Standards on 
The criminal justice environment I describe led journalist and lawyer, Amy Bach, to write Ordinary Injustice: How America Holds Court, a book that examines how those responsible for ensuring that justice is done have come to accept an unjust system. ${ }^{45}$ As these professionals toil in the criminal justice system every day, they slowly lose sight of how far we have fallen from achieving justice. They come to accept the injustice as ordinary. Perhaps Bach's thesis is best summed up by her following observation: "Ordinary injustice results when a community of legal professionals becomes so accustomed to a pattern of lapses that they can no longer see their role in them." 46

I have joined many authors in writing about the embarrassingly low standard of justice that we have come to accept for the most vulnerable among us. ${ }^{47}$ That those professionals charged with ensuring that we live up to our constitutional ideals in our criminal justice system have abdicated their responsibilities in this regard is obvious, and I will not spend much time in this article proving this point. Instead, I turn my attention to the question, "how does a group of people presumably interested in justice come to accept their role in such an unjust system?" For only by understanding how this happens can we begin to discuss how to address this problem.

\section{ORDINARY INJUSTICE: WHEN THE PEOPLE DRIVING A SYSTEM LOSE Sight OF ITS GOALS}

The current dysfunction of our criminal justice system is explained by the concept of organizational culture and how it shapes those who operate within it. Organizational culture is a phenomenon studied by business leaders, and its understanding is considered by those in the business community as essential to leading successful companies. But culture is no less critical in shaping our criminal justice system. ${ }^{48}$ Organizational development theorists define culture as

Collateral Sanctions and Administrative Disqualification of Convicted Persons (Jan. 18, 2002) (unpublished draft) (on file with author).

45 Amy BaCH, Ordinary InJustice: How America Holds Court (2009).

46 Id. at 2.

47 For a discussion, see Shaky Ground, supra note 16; Henhouse, supra note 3; Stephen B. Bright \& Sia M. Sanneh, Fifty Years of Defiance and Resistance After Gideon v. Wainwright, 122 YALE L.J. 2150 (2013); David Cole, Gideon v. Wainwright and Strickland v. Washington: Broken Promises, in CRIMINAL Procedure StORIES 101 (Carol S. Steiker ed., 2006).

48 See generally Jonathan A. Rapping, Directing the Winds of Change: Using Organizational Culture to Reform Indigent Defense, 9 LOY. J. PuB. InT. L. 177 (2008) [hereinafter Winds of Change] (discussing how the principles of organizational culture apply to indigent defense); see Shaky Ground, supra note 16; Jonathan A. Rapping, National Crisis, National Neglect: Realizing Justice Through Transformative Change, 13 U. PA. J.L. \& Soc. CHANGE 331 (2010) [hereinafter National Crisis] (building on Winds of Change to introduce a model designed to begin the reformation of indigent defense; arguing that there is an obligation on the part of the federal government to transform a criminal justice culture inconsistent with our constitutional mandate); Henhouse, supra note 3 (examining the role of culture in shaping the actions of the American prosecutor). 
"[that] set of basic tacit assumptions about how the world is and ought to be that a group of people share and that determines their perceptions, thoughts, feelings, and to some degree, their overt behavior." " thought of as attitudes or mindsets, inform a worldview that is so taken for granted that when asked why one holds it, she might respond, "that's just how things are done around here." 50

The assumptions that influence the members of the organization are a reflection of the organizational values. ${ }^{51}$ When one becomes a member of an organization, his or her outlook and actions are shaped by the value set that defines the organization. The pressure to adapt to the systemic values can be subtle but it eventually defines the perceptions of those who remain in the organization. It is ultimately this set of values that defines the assumptions of every member of the organization.

By way of analogy, think of an organization as a river and the organizational culture as the strong current directing the flow of the water. An individual who wishes to go in a different direction may swim against the current. He or she may even resist the current temporarily. But eventually, the swimmer will tire and either have to get out of the water or become resigned to going with the current. Similarly, when a person joins an organization, He or she may come in with a different value set. But over time, if He or she remains in the organization, their value system will adapt to that of the entity.

Similarly, the criminal justice system is an organization shaped by a value system that defines the assumptions of those who work in it. However, the values that define today's American criminal justice system are a far cry from those envisioned by our Founding Fathers.

At every level, professionals responsible for administering our criminal justice system have abandoned our guiding value system and embraced a set of assumptions that threatens our democracy. Politicians who make important criminal justice policy decisions too often pursue a strategy of demonizing minority populations and the lawyers who represent them because they perceive it as providing short-term political success that trumps any commitment to preserving a justice system that protects the individual and cherishes the right to counsel. Judges consistently focus on strategies to process high volumes of cases through the court system over ensuring that individuals receive justice in each case. Prosecutors routinely prioritize the assurance of quick and certain convictions over the respect for process. And, public defenders frequently accommodate the efficient processing of cases thereby depriving their clients the representation to which they are entitled.

49 Edgar H. Schein, Three Cultures of Management: The Key to Organizational Learning, MIT SloAn MGMT. ReV., 9, 11 (1996).

50 See, e.g., Winds of Change, supra note 48.

51 See id., at 202-04. 


\section{A. Politicians}

Gideon was decided in 1963, a time in our nation's history when we were struggling to ensure that civil rights were equally afforded to everyone. Civil rights activists spearheaded legislative and legal victories that guaranteed equal access in a variety of arenas including voting, commerce, and education. Nowhere were the consequences of these abuses more severe than in the criminal justice arena. Designed to ensure equal access to justice in our nation's criminal courts, Gideon was certainly a critical civil rights victory. But, the nation also experienced growing pains associated with these civil rights victories, and, as with all change, people were divided over the best course of action. As unrest over civil rights led to heightened racial tension, Southern politicians used civil unrest to gain political advantage with working class, white voters. These politicians began a campaign that divided the population along racial lines. ${ }^{52}$ Branding blacks as unAmerican, criminal, and self-destructive, the process of demonizing the black community was used to galvanize white support. Politicians sought to change the narrative of the black American from that of a victim of unjust government policies worthy of protection, to that of a threat to our wholesome, peaceful way of life. Stirring public fear of the black community, and promising the public protection from it, turned out to be an effective political strategy that helped launch a climate of fear that took hold and spread beyond the South.

For example, in California, then-governor Ronald Reagan used raciallycharged rhetoric to rally his white voting base, ${ }^{53}$ and President Nixon, targeting drug use in poor communities of color, ushered in the War on Drugs by labeling illegal narcotics as "public enemy number one." 54 As crack cocaine became popular in the 1980s, and the narrative of violence was built around it, the War on Drugs became a driving influence on America's perception of crime. ${ }^{55}$ With the help of the media that promoted the image of the inner-city criminal as a threat to our social fabric, the criminal defendant morphed from an underdog individual worthy of protection into a menacing force in otherwise lawful communities. ${ }^{56}$ The image of the accused became that of a demonized outsider that society was

52 See Henhouse, supra note 3, at 529-32.

53 Henhouse, supra note 3, at 530, citing STUNTZ, supra note 8, AT 237 (illustrating this by citing Reagan's description of city streets as "jungle paths after dark").

54 Richard Nixon, Remarks About an Intensified Program for Drug Abuse Prevention and Control, (June 17, 1971) (transcript available at http://www.presidency.ucsb.edu/ws/?pid=3047).

55 For a comprehensive discussion of the War on Drugs and how it has influenced criminal justice in America, see Michelle Alexander, The New Jim Crow: Mass InCARCERAtion in the AGE OF ColORBLINDNESS (2010).

56 See Craig Haney, Politicizing Crime and Punishment: Redefining "Justice" to Fight the “War on Prisoners", 114 W. VA. L. REV. 373, 407 (2012); see also ElAYNE RAPPING, LAW AND JUSTICE AS SEEN ON TV (2003) (identifying a shift in "TV series about crime and justice" in which the "defense-attorney hero" has slowly been replaced by heroic policemen and D.A.s). 
told it must fear. As the media fueled the image of the defendant as a demon, politicians found they could gain public support by promising protection from the menace. It was a climate in which anyone running for office had to ensure that he or she was committed to "locking up the bad guys." It shaped political strategies of politicians in both major parties, illustrated by the fact that both George H.W. Bush $^{57}$ and Bill Clinton ${ }^{58}$ used tough-on-crime posturing to win primary elections.

These strategies continue today as systemic values that undermine our foundational criminal justice ideals drive our political leaders. ${ }^{59}$ As several politicians have recently learned, fighting to uphold the right to counsel, and other critical constitutional protections, can be harmful to one's political career. Earlier this year, Debo Adegbile's nomination to head the Department of Justice's Civil Rights Division was blocked by the Senate because of his advocacy - which was his job as defense counsel - on behalf of Mumia Abu Jamal who was convicted of killing a police officer in Pennsylvania. ${ }^{60}$ Similarly, the Republican Governors Association ran an ad attacking South Carolina Democratic gubernatorial candidate Vincent Sheehan for his work as a criminal defense lawyer. The ad accuses Sheehan of "protect[ing] criminals" and "ma[king] money off criminals."61 And on the national stage, anticipating her 2016 run for president, critics attacked Hillary Clinton for her representation of a man accused of rape in $1975 .^{62}$ With

57 Bush's notorious use of Willie Horton, the furloughed Massachusetts inmate who raped and murdered a woman in her home, to defeat Michael Dukakis in the 1988 presidential election is one of the most infamous examples of this strategy. See STUNTZ, supra note 8, at 240; AlexANDER, supra note 55 , at 53 .

58 Then-Governor Bill Clinton made the decision, during the 1992 Democratic primaries, to go back to Arkansas and oversee the execution of a mentally disabled black man named Ricky Ray Rector. See STUNTZ, supra note 8, at 240 . Rector had so little understanding of what was happening to him, that he requested that he be allowed to save his dessert until a later time, not understanding that there would not be another opportunity to eat. See ALEXANDER, supra note 55, at 55.

59 In fact, the "otherizing" of poor people of color has fueled policies that led to the militarization of police forces as politicians persuade the public that society is at war with certain communities. See AleXANDER, supra note 55, at 5. As I write this article, we are witnessing the troubling consequences of such divisive politics on display in Ferguson, Missouri, as heavily militarized police forces treat citizens as though they are our enemies. See Rand Paul, Rand Paul: We Must Demilitarize the Police, TIME (Aug. 14, 2014), http://time.com/3111474/rand-paulferguson-police/.

60 See Ruth Marcus, Ruth Marcus: Blocking the Nomination of Debo Adegbile is a 'Travesty' in the Senate, WASH. Post, (Mar. 7, 2014), http://www.washingtonpost.com/opinions/ruth-marcusblocking-the-nomination-of-debo-adegbile-is-a-travesty-in-the-senate/2014/03/07/ae718948-a63211e3-8466-d34c451760b9_story.html.

61 Ryan J. Rilley, GOP Lawyers Keep Silent on Republican Governors' Attack Against the Legal Profession, HuFF. Post (Apr. 23, 2014, 7:59 PM), http://www.huffingtonpost.com/2014/04/23/republicangovernors-association-lawyers_n_5200254.html.

62 See Melinda Henneberger, Conservatives Are Making Hay out of Hillary Clinton's Defense of an Accused Rapist, WASH. PoST (June 16, 2014), http://www.washingtonpost.com/politics/conservatives-aremaking-hay-out-of-hillary-clintons-defense-of-an-accused-rapist/2014/06/16/7d087efa-f576-11e3-a606946fd632f9f1_story.html. 
seemingly certain future political ambitions, rather than unabashedly reminding her attackers of the noble and indispensable role that defense lawyers play in our democracy, Clinton tempered her defense of her role by making clear that before she undertook the representation, she unsuccessfully asked to be relieved of that responsibility. ${ }^{63}$

Clinton's lukewarm defense of her representation of her client is in stark contrast to the sentiments expressed by John Adams after he volunteered to defend British soldiers accused of what became known as the Boston Massacre. It was 1770 , and there was no less popular case at the time. Adams undertook the representation despite the threat it posed to his political career. ${ }^{64}$ Rather than apologizing for his role, Adams called his defense of these soldiers "one of the best pieces of service I ever rendered my country." ${ }^{65}$ Sadly, today there exist powerful pressures for politicians to abandon the principles that shaped Adams' ideals nearly two hundred and fifty years ago. Appearing tough on crime has trumped the defense of our foundational values. But this posturing came at a great cost. We have lost sight of the humanity of the people accused of crimes, and, in doing so, we have lost respect for the process our Founding Fathers put in place to protect liberty. ${ }^{66}$

\section{B. Judges}

Judges also contribute to a culture that promotes values inconsistent with our founding principles, as they are frequently pressured to prioritize efficiency over

63 See Amy Chozick, Clinton Defends Her Handling of a Rape Case in 1975, N.Y. TimES (July 7, 2014), http://mobile.nytimes.com/2014/07/08/us/08clinton.html?partner=rss\&emc=rss\&_r=3\&referrer.

64 See John Adams and the Boston Massacre, AMERICAN CIVIL LIBERTIES UNION (May 8, 2008), https://www.aclu.org/national-security/john-adams-and-boston-massacre.

65 Robert Mann, The Crime of Our Criminal Justice System: Robert Mann, THE TIMES-PiCAYUnE (July 12, 2014), http://www.nola.com/opinions/index.ssf/2014/07/the_crime_of_our_criminal_just.html.

66 In 2004, I moved to Georgia to join the effort to usher in its new, statewide public defender system. While this effort appeared promising initially, politicians hostile to funding justice soon began cutting necessary funding from the budget. One young public defender wrote a letter to the Atlanta Journal Constitution explaining that she handled 900 cases in the last thirteen months, leaving her only three hours per client if she took no vacation and worked fifty hours per week. See MariePierre Py, Public Defender System Fails Georgians and Their Lawyers, ATLANTA J.-Const., Mar. 30, 2009, at A6. As this young defender, and others like her, decided to leave public defense in Georgia, some state politicians supported further cuts to the indigent defense budget. For example, Senator Preston Smith, Chairman of both the Senate Judiciary Committee and the Legislative Oversight Committee for the Georgia Public Defender Standards Council, the organization tasked with administering the public defender system, wrote a letter to the Atlanta Journal-Constitution accusing indigent defense advocates who rallied against the status quo of demanding "a Lexus-level defense at taxpayer expense." He also accused indigent defense supporters of being "zealots" and "ideologues," while insisting that poor people in Georgia were receiving "[constitutionally] adequate" representation. He suggested that advocates who demanded a greater commitment to public defense were unreasonable. See Preston W. Smith, Should Indigent Defense Oversight be Changed? Pro: Zealots Want Only More of Your Money, AtLanta J.-Const., Feb. 19, 2009, at A14. 
process and to not appear to be "coddling" criminals. Recently, more than a dozen of the best defense lawyers in Houston, Texas protested against a judge who was "coercing defendants to either waive their right to a lawyer or enter a plea of guilty without their lawyer being present." described being in court when the judge brought out eight unrepresented, accused men at once and got them all to plead guilty without providing them lawyers. ${ }^{68}$ This "meet "em and plead 'em" process of disposing of cases quickly is not new to Houston. ${ }^{69}$ In fact it is a common practice in many jurisdictions for judges who want to move cases quickly or save money on paying lawyers. ${ }^{70}$ This practice demonstrates that judges, too, are shaped by influences that are inconsistent with our notion of justice.

That many judges prioritize the efficient processing of cases over justice is demonstrated by the actions of Ohio Municipal Court Judge John Plough who felt justified in ordering public defender Brian Jones to try a case to which Jones was appointed the day before. ${ }^{71}$ When Judge Plough ordered the trial to proceed, Jones requested more time, explaining that he had only twenty minutes to meet with the client to date. The judge denied the lawyer's request for a continuance, holding him in contempt of court when he refused to proceed. ${ }^{72}$

The lack of respect for taking the time to ensure everyone is represented by capable counsel is further evidenced by a couple of letters to the editor written by Georgia trial judges addressing a funding crisis in the state's then newly-formed public defender system. In one letter, clearly unconcerned about the quality of representation, a senior judge in Georgia, who is also a former president of the District Attorney's Association of Georgia and the Council of the Superior Court Judges of Georgia, suggested that the state require all civil lawyers, regardless of their lack of experience handling criminal cases, to handle a certain number of criminal cases free of charge. ${ }^{73}$ Another Georgia judge suggested we go back to offering the "many eager and some starving" local lawyers $\$ 50$ per case, regardless

67 Brian Rogers, Defense attorneys protest Houston judge's procedures, Defense attorneys say misdemeanor jurist's handling of arraignments is 'unethical,' 'unconstitutional,' 'illegal,' HOUSTON CHRON. (June 27, 2014, 8:08 PM), http://www.houstonchronicle.com/news/houstontexas/houston/article/Defense-attorneys-protest-Houston-judge-s-5584669.php\#/0.

68 Interview with Jason Sosa, Attorney, The Sosa Law Firm, in Houston, Tex. (Aug. 5, 2014).

69 Robb Fickman, Judges Must Act to End Jail Overflow, Houston Chronicle (Aug. 9, 2009), http://www.chron.com/opinion/outlook/article/Judges-must-act-to-end-jail-overflow1747232. php.

70 Stephen B. Bright, The Right to Counsel in Death Penalty and Other Criminal Cases: Neglect of the Most Fundamental Right and What We Should Do About It, 11 J. L. SoC'Y 1, 16-17 (2010).

71 State v. Jones, 2008-Ohio-6994, at II 4.

72 The Court of Appeals reversed the contempt conviction, noting that the judge "improperly placed an administrative objective of controlling the court's docket above its supervisory imperative of facilitating effective, prepared representation and a fair trial." Id. at II 32.

73 See Dan Winn, Sharing the Load, DAILY REPORT, Feb. 16, 2010, at 4. 
of the time they invest. ${ }^{74}$ While he never addressed the perverse incentive this creates for lawyers to ignore client interests, he did tout the value of the good relationships local lawyers have with judges and prosecutors. These are just examples of how a culture that responds to systemic pressures inconsistent with justice can shape the judges who are responsible for overseeing court proceedings. $^{75}$

For the judge who chooses to respect our constitutional protections, his career can be placed in jeopardy, as Judge Harold Baer learned when he excluded evidence in a trial after finding the police violated the Fourth Amendment. Judge Baer suppressed evidence of drugs and a confession after finding that the police lacked the requisite suspicion to stop and search Carol Bayless's car. ${ }^{76}$ The decision created a public firestorm with then "Senate Majority Leader and Republican Presidential candidate Robert Dole criticiz[ing] then President Clinton for appointing 'liberal judges who bend the laws to let drug dealers go free' and call[ing] for Baer to be impeached." Clinton responded by criticizing Baer's ruling and announcing his regret for appointing Baer to the bench. ${ }^{77}$ Less than three months after his initial ruling, Judge Baer apparently succumbed to pressure and reversed his ruling. ${ }^{78}$

As a result, many judges simply lose sight of our foundational ideals as other values become the primary drivers in their decision making. Despite the fact that the presumption of innocence is a bedrock principle of our democracy, ${ }^{79}$ a recent article featured a judge in Kentucky who clearly presumes the guilt of many of the

74 Andrew A. Mickle, Is the Process Choking the PD System; Forget the Red Tape: State Should Pay Attention to Funding, but Leave Control up to Local Jurisdictions, DAILY RePORT (Apr. 11 , 2008), http://www.dailyreportonline.com/id=1202552348968/Is-the-process-choking-PDsystem?slreturn=20141130182605.

75 Recently, Timothy Young, Director, Office of the Ohio Public Defender, shared another example of how judges can come to prioritize efficiency over justice, and become hostile to values that may interfere with the expeditious processing of cases, on the website for the National Association of Public Defense. In a post titled The Dark Side, he describes an encounter with a judge who referred to public defense as the "dark side" and complained that "his money" was being wasted by appointing poor people lawyers. See Timothy Young, The Dark Side?, National Association FOR PUBliC DEFENSE (Sept. 10, 2014), http://www.publicdefenders.us/?q=node/526.

76 U.S. v. Bayless, 913 F. Supp. 232 (S.D.N.Y. 1996).

77 This anecdote serves as further evidence of the pressure placed on politicians at the highest levels of government to act with hostility towards unpopular ideals consistent with justice. See New York Federal Judge Reverses Decision in Controversial Drug Case; Clinton, Dole Had Threatened to Ask for Resignation, Impeachment, NAtional Drug Strategy Network, (Apr. 1996), http://www.ndsn.org/april96/bayless.html.

78 Given the political pressure placed on President Clinton from the highest ranking members of Congress, and his response criticizing Judge Baer, this anecdote also further illustrates the point made above regarding those values that drive politicians that are inconsistent with American principles of justice. Id.

79 Mitchell J. Frank \& Dawn Broschard, The Silent Criminal Defendant and the Presumption of Innocence: In the Hands of Real Jurors, is Either of Them Safe?, 10 LEWIS \& Clark L. REV. 237, 248 (2006). 
accused who appear before her and makes no attempt to hide her presumption while presiding. ${ }^{80}$

Another chilling illustration of this can be found in a telling piece by Andrew Cohen called The Death of the Presumption of Innocence, in which he describes how a judge, presiding over the jury selection in a case in which the defendant was accused of sexually assaulting a child, allowed a juror to be empanelled after she made clear she would have trouble presuming the accused innocent. ${ }^{81}$ Few crimes are more likely to inflame a jury, making it especially critical that a judge guarantee all of the constitutional protections designed to ensure a fair process are respected. Yet, this story illustrates how our most essential protections are routinely disregarded by those charged with ensuring justice is served.

\section{Prosecutors}

As troubling as it is to learn of a judge who allows a clearly biased juror to sit in judgment of an accused in such a serious case, it is equally disturbing that the prosecutor in that case worked so hard to rehabilitate a juror who was explicit about her inability to judge the case fairly. ${ }^{82}$ While an impartial jury is at the core of our system of justice, this is an example of a prosecutor more concerned with winning than with pursuing justice. This is not an isolated example of a prosecutor trying to gain advantage by promoting an impartial jury. This unabashed desire to win at all costs also explains how a federal prosecutor sought to inflame jurors' racial biases in an attempt to prejudice them against a man accused of a drug offense. In Calhoun v. United States, the prosecutor, cross-examining an African-

80 Andrew Wolfson, Judge's Remarks Show She Often Assumes Guilt, THE COURIER-JournaL (Sept. 5, 2014, 1:22 PM), http://www.courier-journal.com/story/news/local/2014/09/05/judge-admitsmaking-inappropriate-comments/15121213/.

81 Andrew Cohen, The Death of the Presumption of Innocence, THE WeEK (Apr. 10, 2014), http://theweek.com/article/index/259595/the-death-of-the-presumption-of-innocence.

82 As described in the article, the juror eventually says she could "try" to be fair after the following:

The prosecutor asks a potential juror: "You haven't heard any evidence. How would you vote?" The potential juror responds: "I would have to vote guilty."

Your trial judge pipes up. He's supposed to ensure that you receive a fair trial and that the jurors who will sit in judgment upon you are neutral, objective, and willing to see and hear the evidence with an open mind. The judge asks the prospective juror: "Could you return a verdict of not guilty if the government doesn't prove its case beyond a reasonable doubt?" The would-be juror responds: "I don't think I would be able to."

The prosecutor-who wants this juror on the panel because he wants to convict you-presses on. He asks the juror: "Let's say the victim takes the stand [and] you flatout don't believe her. In fact, you think she's lying. You look at her [and conclude], 'I don't believe a word coming out of her mouth.' Are you going to convict this man anyway?"

The potential juror responds: "That depends. I still feel he was at fault."

$I d$. This was sufficient for the judge and obviously a desirable outcome according to the prosecutor. 
American defendant, explicitly sought to use race as evidence of propensity to sell drugs. To rebut the defendant's claim that he did not intend to associate himself with the drug activity of others around him, the prosecutor asked, "You've got African-Americans, you've got Hispanics, you've got a bag full of money. Does that tell you - a light bulb doesn't go off in your head and say, this is a drug deal?" 83

These are merely two of the countless examples of prosecutors whose desire to accumulate convictions trumps fidelity to all other values. When one understands the role of the prosecutor in our system of justice, it is obvious that this practice is inconsistent with our democratic ideals. Unlike the criminal defense attorney, who is charged with the promotion of the administration of justice through his or her loyal and zealous representation of the accused, the prosecutor serves as a "minister of justice," which demands a broader obligation to ensure that justice is done. ${ }^{84}$

The prosecutor has broad discretion, rendering him or her the criminal justice professional most responsible for directing the administration of justice. ${ }^{85}$ Although charged with acting in the interest of justice at all times, the culture of justice in America pressures prosecutors to develop a "conviction psychology" and to abandon their commitment to justice in an effort to win at all costs. ${ }^{86}$ This mindset can lead prosecutors to work to gain an unfair advantage at trial. Not only have prosecutors been known to try to improperly influence a jury, as discussed above, but also to suppress exculpatory evidence, the disclosure of which is mandated by the Due Process Clause ${ }^{87}$ take advantage of incompetent defense counsel ${ }^{88}$ or intimidate defense counsel in an effort to quell zealous advocacy. ${ }^{89}$

83 Calhoun v. United States, 133 S. Ct. 1136, 1136 (2013) (While Calhoun's petition was denied for other reasons, Justice Sotomayor expressed her disgust at the prosecutor for "suggesting that race should play a role in establishing a defendant's criminal intent." She went on to say, "It is deeply disappointing to see a representative of the United States resort to this base tactic more than a decade into the $21^{\text {st }}$ century . . . We expect the government to seek justice, not fan the flames of fear and prejudice ... I hope to never see a case like this again."). Id. at 1137-38. See also Snyder v. Louisiana, 552 U.S. 472 (2008) (where the prosecutor impermissibly struck all African American jurors and subsequently made references to the O.J. Simpson case in an effort to improperly inflame the passions of the all-white jury).

84 See Henhouse, supra note 3, at 519-23.

85 For an excellent discussion of prosecutorial discretion and the power of the American prosecutor see Angela J. Davis, Arbitrary Justice: The Power of the American Prosecutor (2007).

86 See generally Henhouse, supra note 3; see also Kenneth J. Melilli, Prosecutorial Discretion in an Adversary System, 1992 BYU L. Rev. 669, 686 (1992) [hereinafter Prosecutorial Discretion].

87 JaneAnne Murray, The Brady Battle, Champion, May 2013, at 72. (citing James S. Liebman et al., Capital Attrition: Error Rates in Capital Cases, 1973-1995, 78 Tex. L. Rev. 1839, 1846,1850 (2000)).

88 See Henhouse, supra note 3, at 561 (discussing an example of a prosecutor who joked about taking advantage of a defense lawyer's incompetence). 
But perhaps more troubling than the prosecutor who seeks to unfairly tilt the trial playing field in his or her favor, is the practice of using all tools available to deprive the accused of a trial altogether. As criminal codes have expanded and penalties are becoming increasingly harsh, prosecutors have new tools to force defendants to plead guilty rather than exercise their right to a trial. ${ }^{90} \mathrm{By}$ overcharging counts or charging more serious offenses than the facts will support, prosecutors are able to increase the likelihood of conviction and the certainty of lengthy prison terms. As they inflate the cost of going to trial, prosecutors are able to pressure defendants to plead guilty and waive those protections so necessary to ensure justice.

And, in case these tools provide insufficient leverage to get defendants to waive their rights, prosecutors have used the threat of lengthy pretrial detention, by requesting bonds that poor defendants cannot afford, to further incentivize guilty pleas. ${ }^{91}$ Given that eighty percent of people charged with crimes are indigent, ${ }^{92}$ by requesting bonds that poor defendants cannot make and tying the accused's release to their willingness to plead guilty, prosecutors are able to force defendants to give up their right to trial.

As prosecutors continue to overwhelm the criminal justice system with their charging decisions, they take advantage of these tools to ensure those they accuse cannot afford to demand the rights our Constitution guarantees them. As trials become rare events and prosecutors more readily control the punishment associated with a plea, the jury and judge are stripped of their ability to provide a check against the will of the prosecutor.

\section{Defense Counsel}

In Gideon, the Supreme Court made clear that it is the defense lawyer that serves as the engine necessary to ensure justice is done, for through the right to counsel, all other rights are realized. ${ }^{33}$ But in a system that has lost respect for the right to counsel, defense lawyers - and in particular those appointed to represent the poor-have the passion and zeal beaten out of them as the pressures to process the accused dominates our criminal justice culture. The result is that many defense lawyers have adapted to a status quo that prioritizes the efficient processing of

89 Id. at 562 (discussing an example out of Orleans Parish Louisiana where a prosecutor threatened to charge a defense investigator criminally in an effort to chill constitutionally required investigation).

$90 \quad I d$. at 533 .

91 Id. at 546

92 Mary Sue Backus \& Paul Marcus, The Right to Counsel in Criminal Cases, A National Crises, 57 Hastings L.J. 1031, 1034 (2006) [hereinafter The Right to Counsel in Criminal Cases].

93 See Gideon v. Wainwright, 372 U.S. 335, 344-45 (1963) (recognizing that a layperson will not be able to take advantage of myriad procedural and substantive safeguards designed to ensure fair trials without the assistance of counsel). 
cases and abandoned the values that are fundamental to their duty under the Sixth Amendment. ${ }^{94}$

Much of my scholarship has addressed the pressures that defenders face to abandon their obligations to their clients and to give in to a corrupted set of values that drive our justice system. ${ }^{95}$ Our courtrooms are filled with defenders like Robert Surrency, a lawyer we meet in Amy Bach's Ordinary Injustice who held the contract to represent indigent defendants in Green County, Georgia for fourteen years. Although his position was considered part-time, allowing him to maintain a private practice, Surrency's annual appointed caseload was twice the recommended national standard. ${ }^{96}$ He began his public defender career as a young lawyer and quickly adapted to the expected standards of practice.

The judges demanded that he process his cases quickly, and he obliged. In one four-year period he handled 1,493 cases, with 1,479 (more than 99\%) resulting in pleas. ${ }^{97}$ Some days he would plead dozens of clients in a single court session, and he had little time to get the details necessary to negotiate on their behalf. ${ }^{98} \mathrm{He}$ did not request investigative or expert services, "claim[ing] not to need these resources, anyway, because most of his cases were "pretty open and shut." 99 In addition [h] e didn't want to get people riled up about spending the county's money." 100 When clients complained about the insufficient time Surrency spent talking to them, he chalked it up to "their [bottomless] need for attention," adding, "'You have to draw the line somewhere.",101 Surrency considered his highvolume, plea-bargain practice " a uniquely productive way to do business," and believed that he "achieved good results" for his clients. ${ }^{102}$ Bach concludes that "[u]nder the weight of too many clients to represent, he seemed to have lost the ability both to decide which cases required attention and to care one way or the other." 103

Almost certainly, Surrency did not become a public defender because he wanted to process hundreds of clients each year. But the system shaped him. As young lawyers learn to conform to the values of the system they can develop into leaders who are equally apathetic towards the principles that underlie our justice system. Consider Guy Wilkerson, the president of the Tennessee District Public Defenders Conference, elected to represent public defenders statewide. Wilkerson was invited to testify before the Tennessee House Ways and Means Committee and

94 Shaky Ground, supra note 16, at 173.

95 See The Right to Counsel in Criminal Cases, supra note 92; Winds of Change, supra note 48; Shaky Ground, supra note 16.

96 ORDINARY INJUSTICE, supra note 45, at 12.

97 Id. at 14.

98 Id. at $14-15$.

99 Id. at 15.

$100 \mathrm{Id}$.

$101 \mathrm{Id}$. at 17.

102 Id. at 13.

103 Id. at 15. 
given the opportunity to discuss public defense resources. ${ }^{104}$ Focusing on his own district, he responded as follows:

You all probably could get up here and you're always asking for more and more; but in my district, ... I think I have enough assistants to cover the caseload that I have. I have a five county district. I have an attorney for each county. What I have done is I converted one of my investigators into an attorney position so I could cover all the courts. And uh, then I have one investigator for my five county district. And our caseload, we do about four thousand cases a year. I have been blessed with retention of my staff which means I have experienced attorneys, which really helps a lot in being able to process cases. .. . They get good quality representation. Of course I'm bragging I guess. For one district in the state, . . I think you have supplied what I need . . . ${ }^{105}$

The sheer volume of cases that the conference president's lawyers handleeight hundred per year each-and his attitude about the acceptability of this caseload suggest a district in which every client likely gets representation that falls far short of what justice demands.

Just as Surrency certainly did not decide to become a public defender to process individual clients, Wilkerson surely did not begin his career believing any lawyer could adequately handle 800 cases per year. They, like so many defenders, have been shaped by a culture that is driven by a value set inconsistent with justice. It is the same culture that drives politicians to demonize people accused of crimes and campaign in favor of policies that deprive them access to justice. It is the same culture that pressures judges to abandon their obligation to justice and to focus on the efficient processing of cases. It is the same culture that drives prosecutors to charge more cases than the system is resourced to handle and trample on principles of justice in an effort to coerce defendants into abandoning their rights and pleading guilty. All of these professionals play a role in promoting a criminal justice system that is antithetical to the values that define our democracy.

\section{THE Role OF LAW SCHOOLS IN ADDRESSING OUR CRIMINAL JUSTICE CRISIS}

Prosecutors, defense lawyers, and judges learned to operate within the criminal justice system by internalizing the culture that shapes that system. The

104 Wilkerson is also the district public defender for the Twenty-Fourth Judicial District of Tennessee.

105 Budget Hearing Before the H. Comm. on Fin., Ways and Means, 108th Gen. Assemb. (Tenn. Feb. 7, 2013) at 44:15 (statement of Guy Wilkerson, President of the Tennessee District Public Defenders Conference) (video available at http://www.justicepolicy.org/uploads/justicepolicy/documents/system_overload_final.pdf). 
values that drive them are learned as they participate in the system, and internalized as they see themselves as being effective as that term is defined by the prevailing culture - a culture formed by values inconsistent with justice. As professionals mature in the system, these values subtly shape their views and assumptions, and before long they are perpetuating the existing culture. Because culture is a powerful force that influences everyone in the system, the only way to reform the system is to change the culture. ${ }^{106}$

Changing culture is difficult, but not impossible. Because at its core, culture is determined by the institutional values that shape the perceptions, thoughts, and behavior of those who make up the system, the first step is to introduce a new value set into the organization. As individuals begin to embrace this new value set, and operate in accordance with it, they will begin to internalize these values. Once internalized, the values become the assumptions of the professionals in the system. When enough of the players in the system are guided by the same assumptions, culture will change. ${ }^{107}$

Scholars who study leadership distinguish between adaptive challenges and technical problems. ${ }^{108}$ Adaptive challenges are those that require the people charged with tackling them to adapt their thinking to a mindset necessary to resolve the dilemma. In short, they must change their ways. ${ }^{109}$ Technical problems are easier to fix, as the people responsible for addressing them already have the right mindset and skillset. They address a policy or rule with the tools they already have. "The most common cause of failure of leadership is produced by treating adaptive challenges as if they were technical problems."

To effect the right kind of change, we must understand that criminal justice reformers face an "adaptive challenge," a crisis that requires actors to transform the way they think about justice. Criminal justice actors must embrace a value system consistent with our constitutional ideals. We must guard against treating

106 Many criminal justice reformers advocate for policy reform such as doing away with mandatory minimum sentences, decriminalizing certain behavior, or ending the use of money bonds. All of these are certainly useful reforms, but until the value set that drives criminal justice professionals is transformed they will continue to push the system in a direction inconsistent with justice. The crisis in criminal justice presents an "adaptive challenge" that cannot be rectified with "technical solutions" such as policy reforms. If we are to realize a transformation consistent with the values that are at the heart of our constitution we must get criminal justice professionals to adapt to those values. For an excellent discussion the distinction between adaptive challenges and technical problems see Ronald A. Heifetz \& Marty Linsky, Leadership on the Line: Staying Alive Through THE DANGERS OF LEADING (2002) [hereinafter LEADERSHIP ON THE LINE] (The most common cause of failure of leadership is produced by treating adaptive challenges as if they were technical problems.).

107 Winds of Change, supra note 48, at 204-05.

108 For a discussion of the need for leaders to distinguish between adaptive challenges and technical problems, see LEADERSHIP ON THE LINE, supra note 106, at 13-14.

109 Ronald Heifetz, Alexander Grashow \& Marty Linsky, The Practice of Adaptive LEADERSHIP: TOOLS AND TACTICS FOR CHANGING YOUR ORGANIZATION AND WORLD 69 (2009).

$110 I d$. at 19. 
this crisis as a series of "technical problems" that can be fixed through policies and rules. The primary problem is not that professionals who want to act consistently with justice are kept from doing so by rules that inhibit them from doing soalthough some certainly exist. ${ }^{111}$ While policy reforms can be beneficial, and even force actors to modify their behavior in the short run, unless the value systems that drive those who administer justice are modified, they will continue to be driven to act in ways inconsistent with justice. Ultimately, these actors will find new ways to promote results consistent with their corrupted value system.

If we are serious about transforming our criminal justice system, it is not enough to enact individual policy reforms that will alter behavior in the short-run but leave the values that guide systemic actors unchanged. To realize meaningful reform, we must set about the difficult task of changing the value set that guides institutional players so that they will be guided by ideals consistent with justice. As the community of criminal justice professionals is introduced to a new value set, adapt to it, internalize it, and act consistently with it, the corrupted culture at the heart if the criminal justice crisis will begin to transform. And, as I will argue, the law school itself must be the starting point for this transformation.

At this point, I hope to have established three points: 1) that no metric provides a better gauge of the degree to which we live up to our most important democratic ideals than how we administer criminal justice; 2) that our criminal justice system is currently defined by a set of values that is inconsistent with those ideals, and 3) that transforming our criminal justice system to function consistently with those ideals requires that we redefine the value system that guides those most responsible for its administration. If we agree with these premises, it logically follows that redefining the value set that guides criminal justice actors is essential to becoming a nation that lives up to its most fundamental founding principles. The question then becomes, "what is the most effective way to transform the values that shape criminal justice in America?" Given that the vast majority of professionals responsible for shaping how we administer criminal justice in America are lawyers, ${ }^{112}$ any effort to infuse the system with values consistent with our constitutional ideals must involve law schools.

111 While there will certainly be some professionals who would act more consistently with justice in the absence of rules that constrain them, there are many others guided by a corrupted set of values.

112 Obviously, this is true of judges, prosecutors, and defense lawyers. But, a high percentage of politicians have gone through law school as well. See Joe Patrice, The Return of the LawyerPolitician, AвOve The LAw (Nov. 21, 2012, 4:11 PM), http://abovethelaw.com/2012/11/return-ofthe-lawyer-politician/. ("Of the ['new Congressfolks and Senators'] coming to Washington, 43 percent are lawyers, reversing the decline in lawyer politicians.”). 


\section{How LAW SCHOOLS CAN BUILD AN ARMY OF CHANGE AGENTS}

Each year, when I address the incoming class at Atlanta's John Marshall Law School, I begin with a quote from an unnamed law student: "The first thing I lost in law school was the reason that I came." ${ }^{113}$ I poll the audience to find out why they came to law school. Invariably, a large percentage of them use words like "justice," "fairness," and "equality" in their responses. I then predict that by the end of the first year, many of them will abandon that motivation. My warning is not a comment about AJMLS - in fact, my colleagues there are as committed to preparing and inspiring our students to identify meaningful and fulfilling careers as any faculty I have seen. It is an observation about the way all law schools teach first-year students. We teach them that the law is appropriately reduced to doctrine gleaned from black letters on a white page. We rarely ask about the people behind the cases they will read. The law becomes mechanical, stripped of any human element. We prepare our lawyers to be rational, and to be wary of any emotional response. By making our graduates into robotic technical workers, we ensure the legal profession remains efficient and predictable, at the expense of being compassionate and humane.

It has long been a concern of many within both the academy and the profession that law schools fail to adequately prepare graduates for the practice of law. Ever since Christopher Columbus Langdell, Dean of the Harvard Law School, developed the "case method" in the late $19^{\text {th }}$ century, law students have primarily learned law by reading judicial opinions and analyzing how the courts "interpret and apply the law to a particular set of facts." 114 Through this methodology, students are taught to focus on how to faithfully apply a structured process of analysis to arrive at a conclusion, without questioning "why lawyers in a matter behaved as they did," "what else they might have done," or whether the lawyer's actions were consistent with the client's desires. ${ }^{115}$ They are conditioned to accept the status quo, "becom[ing] 'Monday morning quarterbacks,", who "critiqu[e] the reasoning of others," rather than acquiring "the experience of making decisions under difficult circumstances ...." ".16 For much of the twentieth century, this method of training lawyers went largely unquestioned. ${ }^{117}$

113 William P. Quigley, Letter to a Law Student Interested in Social Justice, 1 DePaUl J. Soc. JUST. 7,8 (2007).

114 Steven C. Bennett, When Will Law School Change, 89 NeB. L. Rev. 87, 91 (2010).

115 Id.

116 Id. at 92.

117 See generally Donald L. Burnett, Jr., Neither Mess Nor Menace: Legal Education and the Erudite Apprentice, 18 PROF. LAw. 2 (2008) (demonstrating that while there are examples of law schools attempting to combine a "graduate school" and "professional school" identity throughout the twentieth century, widespread concerns about legal education did not arise until the latter half of the 1900s). 
But more recently, concerns about how law schools are preparing America's lawyers have grown. ${ }^{18}$ In the last twenty-five years, there have been three major studies that examined the effectiveness of American law schools. ${ }^{119}$ Each of these studies came to similar conclusions; that while American legal education is effective at developing students' analytical ability, they have failed to provide students with the skill set and value set needed to effectively practice law. ${ }^{120}$ Echoing these concerns, numerous legal scholars and professionals have urged law schools to do a better job of preparing students to apply the lessons they learn in the field, and to develop a professional identity and purpose that guides their career. $^{121}$

Through this discourse, many have begun to embrace the idea that we must meet the demand to prepare "practice-ready" lawyers. These critics demand that law schools do a better job at helping graduates develop a skill-set that will enable them to translate the theory they learn into the practice of law in real-world settings. ${ }^{122}$ There is also growing sentiment that law schools need not be agnostic

118 Erwin Chemerinsky, Rethinking Legal Education, 43 HARV. C.R.-C.L. L. REV. 595 (2008) (discussing how "law schools can do a much better job of training lawyers"); Toni M. Fine, Reflections on U.S. Law Curricular Reform, 10 GERMAN L.J. 717, 717 (2009) ("explor[ing] the critiques of U.S. legal education and ongoing curricular changes to the U.S. legal education"); see also Elie Mystal, Law Grads Feel 'Practice Ready,' Employers Seem to Disagree, Above ThE LAW (Aug. 19, 2014, 2:50 PM), http://abovethelaw.com/2014/08/law-grads-feel-practice-ready-employersseem-to-disagree/.

119 American Bar Association, Task Force on Law Schools and the Profession,, Legal Education and Professional Development-An Educational Continuum (1992), available at http://www.americanbar.org/content/dam/aba/publications/misc/legal_education/2013_legal_educatio n_and_professional_development_maccrate_report).authcheckdam.pdf; ROB STUCKEY ET AL., BEST PRACTICES FOR LEGAL EDUCATION: A VISION AND A ROAD MAP (2007), available at http://www.cleaweb.org/Resources/Documents/best_practices-full.pdf; WILLIAM M. SULLIVAN ET AL., The Carnegie Foundation for the Advancement of Teaching, Educating Lawyers: PREPARATION FOR THE PROFESSION OF LAW (2007).

120 American Bar Association, TASk Force on the Future of Legal EduCATion, Report AND RECOMMENDATIONS, 14 (2014), available at http://www.americanbar.org/ content/dam/aba/administrative/professional_responsibility/report_and_recommendations_of_aba_tas k_force.authcheckdam.pdf ("[I]t is commonly stated that the basic purpose of law schools is to train lawyers, however, there is no consensus about what this means.") (emphasis added).

121 Patrick E. Longan, Teaching Professionalism, 60 MerCER L. REV. 659, 659 (2009). "[A]11 professional schools must train their students in 'three apprenticeships:" intellectual, "which develops the knowledge base and habits of the mind that the profession deems important; equipping skills and training, which is necessary to "translat[e] the intellectual training into effective action in practice"; and "inculcat[ing] the student with the values and ideals of the profession." Id.

122 Drew Coursin, Comment, Acting Like Lawyers, 2010 Wis. L. Rev. 1461, 1463-64 (2010) ("Law students spend too much time learning how to think like lawyers, and not enough time learning how to apply that thinking. . . . in order to thrive as professionals, law students must acquire more practical, applicable skills through experiential learning while in law school."); Keith B. Norman, Legal Internships: Helping Students Become Practice-Ready, 75 AlA. Law. 160, 161 (2014) ("The principal purpose of law school is to prepare individuals to provide law-related services. This elementary fact is often minimized. The profession's calls for more attention to skills training ... have been well taken."); Michele R. Pistone \& John J. Hoeffner, No Path But One: Law 
when it comes to promoting values that are core to the profession such as justice and fairness. Proponents of this view argue that law schools should not produce "values-neutral" lawyers, but instead should promote in their curricula values fundamental to the profession. ${ }^{123}$ Under this view, all lawyers, regardless of their ultimate career choice, should be guided by a common set of ideals. And some observers have even embraced the notion that not only should law schools promote a particular value-set, but that it is appropriate for them to inspire students to consider social justice careers. ${ }^{124}$

For law schools that appreciate the need to more effectively teach skills and values, and to inspire students to embark on social justice careers, no model has

School Survival in an Age of Disruptive Technology, 59 WAYNE L. REV. 193, 223 (2013) ("The overly academic nature of the training provided by the Langdellian law school was recognized as a problem almost immediately, became the subject of a law review article in 1917, and then received considerable attention throughout the 1920s.") (footnotes omitted).

123 Christopher L. Eisgruber, Can Law Schools Teach Values?, 36 U.S.F. L. REV. 603, 617 (2002) Perhaps law schools can help students develop a sense of professional identity consistent with the kinds of practice they are likely to have. In theory, at least, law schools might do so by supplying positive . . . role models; by discussing explicitly what it means to live ethically in the law; by illuminating the law's connection to justice and other values; or by introducing students to the intellectual pleasures that can accompany the analysis of legal problems, both in the classroom and in practice."); David Hall, Raising the Bar: A Campaign to Transform the Legal Profession, 22 J. LEgAL Prof. 7, 9 (1998) ("Law schools must create learning environments where [fundamental values to the profession] are cultivated and nurtured[;] . . . . There must be a new partnership between the academy and the profession that nurtures the same values and attempts to find answers to the critical problems facing this profession."); Beverly I. Moran, Disappearing Act: The Lack of Values Training in Legal Education-A Case for Cultural Competency, 38 S.U. L. REV. 1, 24 (2010) ("[B]oth the MacCrate Report and Educating Lawyers asserts that turning students into lawyers requires mastering three skill sets: thinking, practice, and ethics. Nevertheless, the law school world's response to each report is to emphasize only two skills - cognitive and practical—while giving less attention to the third skill-values.").

124 Michael Coper, Law Reform and Legal Education: Uniting Separate Worlds, 39 U. ToL. L. REV. 233, 233 (2008) (stating that the idea that law reform and legal education should be brought together "needs to be defended, especially against a diametrically-opposed proposition that the mission of a modern university is to discover and transmit, neutrally and dispassionately, objective and value-free knowledge, and not to promote, directly or indirectly, a particular point of view, program, or ideology."); Marcy L. Karin \& Robin R. Runge, Toward Integrated Law Clinics that Train Social Change Advocates, 17 Clinical L. REv. 563, 569 (2011) (“[W]e believe a mixture of skills taught and experiences provided to students through [the clinical framework] provides a compelling model to achieve our mutual goal of training students across the county to be effective legal advocates that bring needed and thoughtful social change to their communities."); Jon Mills \& Timothy McLendon, Law Schools as Agents of Change and Justice Reform in the Americas, 20 FLA. J. INT'L L. 5, 6 (2008) ("There is . . a an obligation for universities, and particularly law schools, to be involved in society and promote social justice."); Mae C. Quinn, Teaching Public Citizen Lawyering: From Aspiration to Inspiration, 8 SEATTLE J. Soc. Just. 661, 664-65 (2010) ("[T] he only ethical provision that even begins to address components of public citizen lawyering concepts is [Model Rules of Professional Conduct] Rule 6.1, entitled 'Voluntary Pro Bono Publico Service.' . . . It is only toward the end of [the rule] that lawyers are told they can meet their pro bono responsibility through .... participation in activities for improving the law, the legal system, or the legal profession."”) (footnote omitted). 
been more effective than the clinical model. ${ }^{125}$ While many schools have been reluctant to implement clinics, largely due to the cost, ${ }^{126}$ they have proven to be the most effective method to provide experiential education to students. ${ }^{127}$ Many scholars have written about the benefits of clinical education, and with small student to teacher ratios, close supervision, and the opportunity to work with actual clients and real problems, this model clearly has an educational benefit that is missing from traditional legal teaching. ${ }^{128}$ My own experience bore this out. During my third year of law school, I participated in a criminal defense clinic representing misdemeanants in D.C. Superior Court. Outside of the mentorship and guidance I received as an intern at the Public Defender Service for the District of Columbia, ${ }^{129}$ no other law school experience better prepared me for my work as a public defender.

But, in retrospect, I recognize a flaw in my clinical experience. I spent a year learning how to represent three clients really well. With no limit on the amount of time or resources available to give my clients the representation they deserved, I honed my craft in an artificial laboratory and learned the way a defense lawyer is supposed to represent a client. I never learned about all of the challenges that make this standard of practice impossible for most public defenders. I was never introduced to the very real pressures defenders face to allocate scarce resources. I was prepared to practice in a model defender office. And fortunately for me, I began my career in one of the very few such offices that exist in this country. ${ }^{130}$

125 Suzanne Valdez Carey, An Essay on the Evolution of Clinical Legal Education and Its Impact on Student Trial Practice, 51 U. KAN. L. REv. 509, 527 (2003) (“Advocates of clinical legal education emphasize that low student-faculty ratios and a learning environment in which continuous critical assessment and feedback is given by faculty members imparts and fosters practical legal skills and assists in developing a well-rounded lawyer who will continue to learn from his or her own experiences after graduation from law school."); Brent E. Newton, Preaching What They Don't Practice: Why Law Faculties' Preoccupation with Impractical Scholarship and Devaluation of Practical Competencies Obstruct Reform in the Legal Academy, 62 S.C. L. REv. 105, 140 (2010) ("Clinical training involves more than mere skills training; it 'give[s] students systematic training in effective techniques for learning law from the experience of practicing law,' which is vastly superior to learning from reading appellate cases and then listening to a professor lecture or employ the casedialogue method.") (footnote omitted).

126 See Erwin Chemerinsky, Why Not Clinical Education?, 16 CliniCAL L. Rev. 35, 38 (2009) (noting the economic advantage to teaching through the casebook method, the author argues that the primary reason schools have not embraced the clinical model is cost).

${ }^{127} I d$. at 35 (arguing "[t]here is no better way" than clinics to teach students skills and professional values).

128 Id. at 38 .

129 I interned at PDS both of my law school summers and throughout my second and third years of law school. Therefore, most of my legal education, even while in law school, came from this experience.

${ }^{130}$ I began my career at the Public Defender Service for the District of Columbia (PDS). PDS is nationally regarded as one of the best public defender agencies in the country. See Barbara A. Babcock, The Duty to Defend, 114 YALE L.J. 1489, 1493 (2005) (describing PDS as "a model 
But after working in some of the more typical criminal justice environments in the country, I realize my clinical education had not prepared me to be a public defender in most American courtrooms. Had I began my career in Georgia, Louisiana, Mississippi, or any of the terribly broken systems across the country, I would have been paralyzed. No one taught me how to translate the lessons I learned to address these challenges. I would have very quickly abandoned these lessons to learn the shortcuts the system demands defenders take to survive.

I now realize that if law schools are going to live up to their potential to contribute to the reformation of our criminal justice system, they must do more than effectively teach skills and professional values. Teaching best practices and sending students to systems that do not respect those practices will not serve them well. Assuming law schools were able to effectively prepare graduates to apply the lessons they learned in law school and to inspire these students to pursue careers consistent with a sense of justice and fairness in systems where they are most needed. The theory behind organizational culture teaches that if these young lawyers practice in systems driven by a culture inconsistent with those values, they will soon be forced to leave these systems or succumb to the status quo. ${ }^{131}$ In short, the law school that accepts the broken system as a given-or never even considers the health of the system - will not be part of the solution. Being the best lawyer one can be, but accepting the dysfunction of his or her environment, will not lead to change. Law schools must prepare students to change the values in systems in need of reform. ${ }^{132}$

To summarize, if law schools are to help fix the criminal justice crisis in America they need to: 1) prepare students with a knowledge base and skill-set to be excellent criminal lawyers, 2) inspire students to want to pursue careers in criminal justice, 3) ensure students embrace a justice-based value set, and 4) make sure students are aware of the systemic challenges to practicing consistent with this value-set and provide them strategies for resisting pressures to abandon these values. Law schools must train students to broaden their view of what a lawyer can do in a broken system.

agency"); see also Richard Delgado, The Current Landscape of Race: Old Targets, New Opportunities, 104 Mich. L. REV. 1269, 1273 (2006) (describing PDS as "nationally prominent").

131 See Karen H. Rothenberg, Recalibrating the Moral Compass: Expanding "Thinking Like a Lawyer" Into “Thinking Like a Leader", 40 U. TOL. L. REV. 411, 416 (2009) (recognizing the role law schools play in training students to resist pressure to abandon important lawyering values, the author says " $[\mathrm{T}]$ he current paradigm in legal education is not providing lawyers with the training and skills necessary to maintain their moral compass over the course of their careers.") (footnote omitted).

${ }^{132}$ It was this realization that led Gideon's Promise to begin to invite criminal defense clinicians to our annual Trainer Development Conference, mentioned below. See infra text accompanying note 149; Shaky Ground, supra note 16, at 175-80. Originally developed to teach public defender trainers a model for teaching public defenders to raise the standard of representation in challenging environments and to withstand pressures to process clients, in 2012 we began inviting criminal defense clinicians to this conference in the hopes of getting more clinicians to consider how to inspire and prepare students for careers in challenging environments. 
It is this last piece that is missing from even the most innovative curricula. And yet, this is the most critical piece if lawyers are to become part of a strategy to transform culture. To address the challenge facing our criminal justice system, lawyers must learn to not only be excellent advocates, but must also become change agents. ${ }^{133}$

\section{FROM LAW SCHOOL TO PRACTICE: \\ SEEING How OUR CURRICULAR SHORTCOMINGS Play OUT IN REALITY AND CONSIDERING HOW TO EFFECT CHANGE}

I spent the first decade of my legal career working in a model public defender office, before moving to Georgia to begin a career working with public defenders in broken criminal justice systems. Over the next decade I worked closely with public defenders in some of the most challenging environments across the Deep South. It was not until I began this second phase of my career that I came to understand how ill-prepared our law school graduates are to represent people accused of crimes. Many had never learned concepts and skills foundational to criminal defense work. Many had little appreciation for the role of the defender in promoting justice and how to use a comprehensive tool kit to carry out their duty. I began to understand that these defenders needed to learn lessons about representing poor people accused of crimes and possess a set of skills they were never taught in law school, and to understand how these lessons could be used in concert to better represent their clients.

But, I also realized that we faced a greater challenge if we were to live up to the promise of Gideon. It was only after I began to work in the most challenging environments that I came to appreciate the importance of teaching lawyers a justice-oriented value set, and supporting them as they struggle to practice consistently with it. Only then, did I begin to realize the power of a community of professionals, driven by a common set of values, to transform organizations and systems in need of reform.

For my first decade of practice as a public defender, I experienced, and took for granted, a system that respected the right to counsel and afforded poor people accused of crimes the type of lawyer that they were constitutionally guaranteed. ${ }^{134}$ Every lawyer began his or her tenure at the Public Defender Service for the District of Columbia [PDS] with an intensive training program that taught substantive law, procedure, and skills. ${ }^{135}$ All of these lessons were taught against the backdrop of a

\footnotetext{
133 See Rothenberg, supra note 131, at 413 ("In an ideal world, young lawyers would . . be more attuned to their own values, and have the moral courage necessary to be leaders and agents for change in their profession.").

134 See National Crisis, supra note 48, at 347-48.

135 When I began at PDS, the training program lasted six weeks. Since then it has evolved into a nine-week training program. All lawyers must go through this training before being appointed a client.
} 
strong culture that promoted client-centered values. ${ }^{136}$ They were reinforced through continuous training and supervision as each lawyer matured into a seasoned defender. I spent five years as a supervising attorney and three as the Training Director, always assuming that the system expected our lawyers to provide excellent representation. ${ }^{137}$ Our focus was on providing every client the best representation possible, not on fighting against pressures to deprive clients the lawyers they deserved. I was unaware that the system within which I operated was such an exception, and that in most of the country a respect for the right to counsel did not exist.

Because I learned so much about how to be a public defender from my time at PDS, ${ }^{138}$ I did not see the shortcomings of my legal education. Rather than focusing on how poorly law school prepared me for my legal career, I took in all I could about how to be a great public defender from my eleven years of on-the-job training. Then, in 2004 I was invited to become the first Training Director for the state of Georgia when it unveiled a statewide public defender system. And in 2006, I joined the effort to rebuild the public defender system in New Orleans in the wake of Hurricane Katrina, serving as the Director of Training and Recruitment. Being in on the ground floor of two indigent defense reform efforts was eye-opening. My first years in the South exposed me to a culture that accepted an embarrassingly low standard of justice for poor people and expected public defenders to facilitate that injustice. And I met countless public defenders who, although well-intentioned, were ill-equipped to defy these expectations. Their legal training failed them in several fundamental respects.

First, their coursework was often incomplete, as essential courses in criminal law and procedure are frequently not required, ${ }^{139}$ and many students do not recognize their importance prior to graduation. To the extent that relevant courses are offered, they are often taught in isolation with no attempt to integrate various criminal law courses into a comprehensive curriculum. As a result, even if a student were to take criminal law, criminal procedure, and evidence, it would likely be taught by three distinct teachers who did not coordinate with one another and who never considered how lessons from the other courses impact what each is teaching.

Secondly, in addition to probably having missed out on a comprehensive and integrated curriculum, these lawyers were frequently never taught how the lessons

\footnotetext{
136 For a discussion of client-centered representation and the values consistent with it, see Shaky Ground, supra note 16.

137 There was certainly much about the criminal justice system in DC that was unjust, but PDS had long before my arrival established a high standard of practice that became the accepted norm by the time I arrived.

138 See Babcock, supra note 130; see Delgado, supra note 130.

139 For example, in many law schools a basic criminal procedure course that covers the Fourth, Fifth, and Sixth Amendments is not required, and I am unaware of any that requires a course in criminal procedure that covers topics beyond these.
} 
they learned actually applied in practice. So a law graduate may have learned the doctrine behind the Fourth Amendment without ever learning how to raise and litigate a suppression issue. Or, he or she may have learned about statutory discovery without having learned how to effectively use discovery to advance the goal of the particular litigation. ${ }^{140}$ And because law schools compartmentalize courses, even when they attempt to teach skills, students are not provided an opportunity to appreciate how the substantive courses relate to the skills being taught. ${ }^{141}$

Third, and most importantly, many of these lawyers were coming out of law school with a value set that is inconsistent with the role of defense counsel. ${ }^{142}$ I witnessed public defenders that refused to file motions for their clients because they were afraid of getting the judges upset, ${ }^{143}$ others who came to accept a system that detained poor people for weeks after arrest without meaningful access to counsel, ${ }^{144}$ and others still who simply did not respect the people they represented. ${ }^{145}$ I heard myriad stories of lawyers for the poor who lost their zeal to represent their clients, ${ }^{146}$ and because they were guided by a corrupt value system, these lawyers often did not appreciate how their educational shortcomings in the first two areas rendered them a less qualified lawyer. ${ }^{147}$

\section{A. Grooming Reformers: Reimagining How We Teach Lawyers to Restore Our Democracy}

It was at this time that I became a student of organizational culture and came to truly appreciate how this system of injustice came to be tolerated by everyone in

\footnotetext{
140 For example, skilled criminal defense lawyers understand that discovery can be a tool to gather information as well as to try to set up the exclusion of evidence. How the lawyer requests information pursuant to the applicable discovery statute and subsequently litigates issues that arise are functions of the goal of the representation.

141 For example, the norm for a trial advocacy course is to start with a set fact pattern. The facts are taken as given. This is where the lawyering begins. In reality, the bulk of the lawyering goes into shaping the universe of facts that will be used to try a case. Through investigation, discovery, motions practice, client interviewing, and a host of other vehicles, the lawyer is continuously both gathering information and seeking to exclude evidence that is harmful to his or her case. See Jonathan A. Rapping, Evidence Blocking: How the Defense Can Define the Legal Landscape At Trial, 33 Am. J. TRIAL Advoc. 1 (2010). But trial advocacy courses often inadvertently send a message that minimizes the role the lawyer plays in developing the facts available at trial.

${ }^{142}$ Shaky Ground discusses some of the values that are fundamental to the work of defense counsel including: 1) a duty of loyalty to the client, 2) a duty to zealously advocate the client's cause, 3) a duty to be thorough and prepared, and 4) a duty to communicate with the client. See Shaky Ground, supra note 16, at 164.

143 See National Crisis, supra note 48, at 348.

144 Winds of Change, supra note 48, at 189-90.

145 See National Crisis, supra note 48, at 348.

146 For discussion, see Winds of Change, supra note 48; see also Shaky Ground, supra note 16; see also National Crisis, supra note 48.

147 See Winds of Change, supra note 48, at 191.
} 
it. While I was involved in training public defenders across the country, I came to realize that defenders need a comprehensive understanding of how all of these lessons work together to advance the representation. But, even a program that does this will not be sufficient when defenders are driven by a value system inconsistent with what their clients deserve. I also saw that a one-time training program-no matter how good-could never counteract the continuous and pernicious influences the lawyer would return to when the instruction concluded.

My experience and study taught me that public defenders needed to be taught a new set of skills and values, and provided ongoing support as they fought against the pressure to abandon these ideals. The realization of the role that culture plays in shaping public defenders led me to develop an organization committed to building a community of public defenders with the support necessary to resist these cultural pressures as they developed into a movement of advocates who would drive criminal justice reform. And so the non-profit, Gideon's Promise, was born.

After I began my law school teaching career, I began to also focus on how these cultural forces shape other players in the criminal justice system. As I considered my role as a law school teacher, against the backdrop of my experience in the criminal justice arena, I began to appreciate just how critical a role law schools could play in grooming a generation of graduates to reshape a criminal justice system that lives up to our constitutional ideals. I began to understand that law schools have the potential to instill important values in law students, and to provide graduates the strategies necessary to retain these values as practicing lawyers in systems that are hostile to them. With this insight, I welcomed the opportunity to develop a comprehensive curriculum, based on my work in the field with public defenders, that would allow my law school to begin to live up to this potential. Thus, the Honors Program in Criminal Justice at Atlanta's John Marshall Law School was born.

A brief discussion of the philosophy behind Gideon's Promise, and how it informs the curriculum of the Honors Program in Criminal Justice, will help to illustrate how law schools can help address our criminal justice crisis.

\section{B. Gideon's Promise}

In 2007, my wife and I founded Gideon's Promise ${ }^{148}$ in order to develop a community of skilled, passionate, ethical public defenders that would introduce a new value-set into the systems within which they work in an effort to begin to transform the existing culture of injustice. At the heart of this transformative model is the three-year Core Program, designed to recruit, train, and support new public defenders as they both work to raise the standard of representation for their clients immediately and begin the process of developing into tomorrow's indigent

\footnotetext{
148 At the time it was founded, the organization was named The Southern Public Defender Training Center. The name was changed to Gideon's Promise in 2013.
} 
defense leaders. Through a process of "values-based recruitment, training, and mentoring," 149 Gideon's Promise seeks to identify defenders who are receptive to a desired set of values, ${ }^{150}$ teach them how to practice consistently with these values in challenging environments, and provide ongoing guidance as they struggle to remain true to these values as they develop as lawyers.

The Gideon's Promise Core Program is unique in several ways. First, each new class begins its three-year experience with a fourteen-day training that teaches more than two-dozen topics foundational to the work of the public defender. These sessions build on one another, and faculty constantly stress that they are each part of a toolkit that must be used in concert to effectively represent the client. They are examined in the context of a hypothetical case the class prepares over the two weeks, illustrating how each is an integral part of the larger representation, with the result dependent on how the lawyer handles every aspect of the case. In order to ensure that the faculty members are coordinated in the presentation of these materials, each must complete the Gideon's Promise Trainer Development Program ${ }^{151}$ to learn the curriculum and how each session fits into the broader goals of the training.

Second, each session is designed to ensure the participants understand how the topic is applied in practice. The trainees' performance during workshops determines the information they learn about the case, or whether they can successfully suppress or exclude evidence, enabling them to appreciate how their decisions impact the outcome of the litigation.

Finally, while this model that teaches substantive law, procedure, and skills in an integrated and applied way is innovative and distinctive, what makes the model truly unique is its focus on teaching lawyers a set of values, identifying systemic challenges to practicing consistently with those values, and working with them to develop strategies to overcome these hurdles. ${ }^{152}$ Throughout the curriculum,

149 See Shaky Ground, supra note 16, at 175-80.

150 Gideon's Promise has established partnerships with over 35 public defender offices from fifteen states (AL, AZ, GA, KY, LA, MS, PA, NE, NC, NY, SC, SD, TN, TX, and WV). Lawyers with less than three years' experience as a public defender from any of our partner offices are eligible to apply. Gideon's Promise also helps recruit recent law graduates to join partner offices. Gideon's promise welcomes a new class each summer. The smallest class included 16 defenders in 2007 . In 2014, we welcomed sixty public defenders, our largest class to date. In 2014 Gideon's Promise established a partnership with the state of Maryland, the first time Gideon's promise will apply its model to a statewide public defender system.

151 For more information about the Trainer Development Program, visit Trainer Development Program, GIDEON's PROMISE, http://gideonspromise.org/trainer-development-program/ (last visited May 25, 2015).

152 An example of this can be seen in how Gideon's Promise teaches lawyers to resolve ethical dilemmas consistent with client-centered values. Every law graduate learns the Rules of Professional Conduct. Rule 1.6 establishes a duty of confidentiality requiring a lawyer to refrain from sharing "all information relating to the representation, regardless of the source." See ModEL RULES OF PROF'L Conduct R. $1.6 \mathrm{cmt} .3$ (2013). Rule 3.3 requires a duty of candor to the tribunal. See Model Rules of PRof'L CONDUCT R. 3.3 (2013). While every lawyer should have learned these two rules, few are 
instructors push students to identify core values and impediments to acting consistently with them before working through various responses to these challenges. ${ }^{153}$ Because discussions of the values are not isolated in a single, discreet session, but instead are woven throughout the entire curriculum, participants appreciate that these values must drive every decision they make.

Recognizing the power of a corrupt culture to reshape even the most committed professional, Gideon's Promise provides ongoing support to its lawyers as they work to practice consistently with this value-set in hostile environments. These lawyers are connected to a community of like-minded advocates who reinforce the lessons taught. ${ }^{154}$ To provide further support and more readily drive systemic change, Gideon's Promise has developed a comprehensive community of change-agents that collectively work to infuse the criminal justice system with a set of values consistent with justice. ${ }^{155}$ And while this model is essential to ensure

taught how to resolve tensions between them consistent with justice driven values. One such value is the duty of loyalty to the client. See Shaky Ground, supra note 16, at 164-65.

Once we teach this value, and what it means, we then introduce a challenge to practicing consistently with it. For example, imagine a client, charged with possession of cocaine, shared with his lawyer that he had a prior conviction for possession of cocaine. Suppose a judge, considering a defense request for pretrial release, is unaware of any prior convictions. How should defense counsel respond to a direct request from the judge about whether the client has any prior convictions? What if the judge pushes harder to get the lawyer to answer?

Once we introduce the challenge, we start to examine possible strategies for resolving the dilemma. We start by examining a spectrum of responses. Some are clearly unethical. The lawyer who says, "My client absolutely has no prior convictions," is likely in violation if Rule 3.3. The lawyer who says, "Yes, my client has a prior conviction for possession of cocaine," is clearly in violation of Rule 1.6.

As we examine unethical responses, we also consider the likely motivation of the lawyer. The first lawyer is motivated by loyalty to the judge, or an assumption that his obligation to the judge trumps any obligation to the client. The second lawyer is motivated by loyalty to the client.

Then, through simulated courtroom scenarios, we have the students work to resolve the dilemma, invariably eliciting a host of responses that fall along a spectrum-some being more consistent with the value of client loyalty than others. "I am not at liberty to share that with you," "What my client shares with me is confidential," "I have not verified anything that suggests my client has any prior convictions," "I have no information that I am able to provide the Court." For each, we discuss the ethical propriety and the extent to which the response is beneficial to the client. As the judge (played by a faculty member) pushes ("Well, have you asked your client?") we can explore the students' understanding of the ethical limits. In this setting, the lawyers can solidify their understanding of their obligation to each client, anticipate challenges that make it challenging to remain loyal to the client, and develop a set of responses to push back against these pressures.

153 Impediments might be a judge pushing a lawyer to withdraw a motion because she is more concerned with moving the case quickly or a prosecutor threatening to withdraw a plea if the lawyer insists on having time to investigate or litigate important legal issues.

154 During the three-year Core Program, members are given mentors who reinforce these lessons in the field, and gather as a collective community every six months for follow-up training and community building. Since its inception, Gideon's Promise has trained over 300 defenders who embrace a common vision and have adopted a shared value-set.

155 Gideon's Promise has since developed a Graduate Program to continue developing its graduates into trainers, mentors, and future leaders; a Leadership Program to work with the chief public defenders it partners with as they consider how to best support their young lawyers and infuse 
that the new defender continues to be guided by the taught value-set throughout his or her development, thereby contributing to the necessary reform, it is the curricular component of this model that is most instructive for law schools if they are to contribute to the effort to populate the criminal justice system with the change agents so desperately needed.

\section{Honors Program in Criminal Justice}

I joined the faculty of Atlanta's John Marshall Law School in 2007 because of the opportunity to help educate future criminal justice professionals and the school's stated commitment to developing lawyers committed to social justice. ${ }^{156}$ I was just beginning to build Gideon's Promise and saw a synergy between my work with indigent defense and the mission of the law school. Fortunately, the faculty at AJMLS also saw this as a unique opportunity to help better prepare our graduates interested in criminal law, and in $2011 \mathrm{I}$ was invited to develop the Honors Program in Criminal Justice. ${ }^{157}$ Inspired by my work with Gideon's Promise, the Honors Program was developed as a three-year curriculum that sought to integrate a comprehensive criminal law curriculum, to teach students how the substantive law and skills taught apply in practice, and to both instill in students a justicefocused value-set and prepare them to practice consistently with that set of values throughout their careers. And because the Honors Program was designed to train criminal justice professionals generally, it provides an opportunity to spread the influence of the Gideon's Promise model more broadly. ${ }^{158}$

The Honors Program uses an innovative curriculum to prepare a new generation of criminal justice professionals. For starters, the program teaches a core selection of criminal law related courses in an integrated manner. Criminal Law, Criminal Procedure (both investigation and adjudication), evidence, and advanced evidence (introducing forensic issues and other topics relevant to the practice of criminal law today) are all taught by a faculty of teachers that meet

their offices with this shared value-set; a Trainer Development Program to ensure all trainers embrace, and understand how to teach the curriculum, as well as to teach it to teachers beyond the Gideon's Promise community in an effort to export the model; and a Law Clerk Program to inspire and prepare future public defenders to join the effort to transform public defense in systems most in need of reform.

156 According to its mission, AJMLS is committed to educating students "who show promise of making positive contributions to the profession, legal system or society," and is "dedicated to preparing highly skilled, ethical, and professional lawyers who possess a strong social conscience." See Mission, John Marshall LAW SchOOL, http://www.johnmarshall.edu/about/mission/ (last visited May 25, 2015).

157 To learn more about the Honors Program in Criminal Justice, visit https://www.johnmarshall.edu/futurestudent/j-d-honors-program-in-criminal-justice/.

${ }^{158}$ For the first three years, the Honors Program welcomed small classes of less than twenty students. These students began the Program upon entering AJMLS. As the demand from existing students has grown, we are in the process of modifying the curriculum to accommodate students who wish to join after the first year. 
regularly to coordinate instruction. In this way, teachers can reinforce lessons from other courses and ensure students appreciate how issues overlap. Using a simulated case, students build a case file over their first two years, receiving documents relating to the case file in each of the core courses as the respective issues are introduced. ${ }^{159}$ As new material is provided, the simulated case file is developed, allowing students to both discuss new issues and revisit prior discussions. Because these courses are taught over the first two years, students are forced to continue to think about how lessons from the first year are impacted by these new revelations.

In order to ensure that students appreciate how these lessons are applied in practice, they take a six-credit hour Integrated Advocacy Course through which they engage in simulated pretrial litigation and trial advocacy using the case file they built during the core curriculum described above. This capstone course ensures the students reassess the case with a complete file while having a firm grasp of how lawyering decisions from the beginning of the case informed the content of the file. This course provides a clear understanding of how these earlier decisions impact the larger litigation strategy while also illuminating the interplay between legal doctrine and lawyering skills.

In addition to requiring the above-mentioned courses, students in the Honors Program must take an additional credit hour of both criminal law and criminal procedure (investigation), both of which are offered in the first year. ${ }^{160}$ This allows the professors to spend additional time discussing the simulated case that is the vehicle through which the core curriculum is integrated, and focusing on how lawyering decisions might have impacted the cases discussed and the values that likely motivated the behavior of the criminal justice professionals behind the cases.

The students are also explicitly introduced to lawyering values, taught how the existing criminal justice system can be hostile to those values, and pushed to consider how criminal justice professionals can practice in accordance with these values. In their first year, students take a two-semester course called Criminal Justice Lawyering ${ }^{161}$ through which they consider what justice means and the role of various criminal justice professionals in promoting justice. Through books, articles, documentaries, and outside speakers, students gain insight into how our

159 For example, in criminal law students receive basic police reports and defense investigative memos as they discuss the appropriate charging decisions, possible defenses, and tasks that prosecutors and defense lawyers need to do as more information is revealed. In criminal procedure (investigation), students receive additional documents that raise issues about the evidence collected (physical evidence, statements, and identifications). In criminal procedure (adjudication), documents introduce additional procedural issues such as how to effectively raise discovery, Brady, or severance issues. Documents provided in evidence and advanced evidence raise additional issues corresponding to the material taught.

160 While the traditional curriculum requires three credit-hours each of criminal law and criminal procedure, Honors program students take four credit-hours of each.

161 The name of this course was changed from Introduction to Criminal Justice to more accurately reflect its content. 
criminal justice system operates in reality and explore the extent to which it functions in accordance with our aspirational ideals. Students are pushed to examine where our system falls short of these ideals and the role of criminal justice professionals in facilitating this justice gap. Finally, they are asked to consider how they might respond to systemic influences inconsistent with these ideals.

These values are revisited throughout the three-year curriculum. In the third year, in addition to taking a course in criminal law ethics, the participants spend two semesters in a criminal justice related externship through which they can gain insight into how the issues raised in the program manifest themselves in reality. While going through their externship, they participate in a weekly class designed to prod them to explicitly apply the programmatic lessons to their actual experience. $^{162}$

In this sense, graduates of the Honors Program will enter the profession with a comprehensive knowledge of criminal law, an appreciation for the interplay between the substantive courses they took, an understanding of how to apply the lessons learned in practice, and a foundation that allows them to do so consistent with a core value-set essential to live up to the American notion of justice.

\section{CONCLUSION}

In stark contrast to the fundamental ideals enshrined in our Constitution, the American criminal justice system as it now exists is largely defined by a set of values that is inconsistent with justice. Ours is a system that dehumanizes certain populations, and therefore embraces a lesser standard of justice for members of those communities. ${ }^{163}$ This value set shapes the professionals responsible for administering it, who in turn perpetuate a system of injustice. Because these internalized values lead criminal justice professionals to pursue outcomes inconsistent with justice, changing the rules that govern their behavior will be of limited value in driving reform. While policy reform may force those who administer the system to play by a different set of rules, until they are guided by a new set of values they will continue to work to achieve results inconsistent with justice.

Therefore, if we are serious about realizing a system of justice that is fair and equal, we must transform the value set that drives our politicians, judges,

162 Although, a shortcoming of the curriculum is that AJMLS does not offer a criminal law clinic, so that students can apply the lessons taught in the program under the tutelage of faculty members who understand the curricular goals and how the clinical experience is designed to fit into the larger teaching methodology.

163 See Jonathan A. Rapping, Keynote Address, Reclaiming Our Rightful Place: Reviving the Hero Image of the Public Defender, 99 IowA L. REV. 1893, 1903 (2014) (arguing that our lack of commitment as a society to ideals consistent with justice is driven by our perception of those accused of crimes as less than human). 
prosecutors, and defenders. Because so many of these professionals are lawyers, our nation's law schools play a critical role in promoting a just society.

Law schools have been criticized for their failure to adequately educate future lawyers, but the bulk of the criticism has focused on legal academia's failure to teach skills and values necessary to effectively practice law. Recognizing academia's obligation to develop lawyers committed to the public interest, a smaller group of critics have also challenged law schools to inspire students to consider social justice careers. But if we are to transform legal systems designed to drive unjust outcomes, we must do more than equip law graduates with the skills and values necessary to be effective practitioners and steer them into careers that serve the public interest. We must ensure that they appreciate the challenges they will face as they strive to provide clients with what they deserve and arm them with strategies to change those systems. If our graduates are to resist systemic pressures to accept the status quo, they need more than law schools currently provide.

Teaching law graduates to be as effective as possible within broken systems is not good enough. We must begin grooming a generation of change agents prepared to infuse legal systems with values consistent with justice.

Nowhere is this mission more important than in the criminal justice arena. If law schools are to live up to their obligation to produce lawyers who help create a more just society, they must start by preparing criminal justice professionals to challenge the status quo.

In a 1910 address to the United Kingdom House of Commons, Sir Winston Churchill famously said, "[t]he mood and temper of the public in regard to the treatment of crime and criminals is one of the most unfailing tests of the civilization of any country." The mood and temper to which he refers is a reflection of our values. We cannot alter our demand for justice, and therefore, our will to engage in the hard work of reform, without recalibrating the values that guide us. This mission is as important as any that a law school might embrace. 